\title{
TETRACYCLINE REMOVAL FROM WATER BY ADSORPTION ON GEOMATERIAL, ACTIVATED CARBON AND CLAY ADSORBENTS
}

\begin{abstract}
The use of antibiotics for breeding and for humans increased considerably in recent years, as a dietary supplement to enhance animal growth. This frequent use leads to the detection of residues in water and wastewater. Thus, the emergence of new strains of bacteria resistant to these antibiotics and, can lead to incurable diseases of livestock, and can lead to a possible transmission of these strains to humans. The purpose of this work is to develop new materials based on treated Maghnia clay, activated carbon, cement, and PVA polymer, named geomaterials. These materials were intended for the containment of hazardous wastes in landfills. The removal of tetracycline from aqueous solution was tested by adsorption onto synthesised geomaterials and their mineral constituents. Adsorption kinetics revealed that tetracycline was rapidly retained by GM and ATMa. This was confirmed by the relatively short equilibrium time of $30 \mathrm{~min}$. The pseudo-second-order and intraparticle models well fitted the adsorption kinetic of the TC-adsorbent studied systems. It was noticed that the adsorption kinetic passes through several mechanisms, was demonstrated by the multi-linearity on the plot of $q_{t}$ against the square root of $t$. The adsorption capacity $\left(Q_{a}\right)$ of TC onto GM is $\mathrm{pH}$-dependent. Indeed, $Q_{a}$ reaches a maximum value $\left(Q_{a}=12.58 \mathrm{mg} \cdot \mathrm{g}^{-1}\right.$ at a very acidic $\mathrm{pH}$ of 2 , then the adsorbed amount decreases to reach a minimum value at $\mathrm{pH}$ of 8 , and for basic $\mathrm{pHs} Q_{a}$ increases up to $10 \mathrm{mg} \cdot \mathrm{g}^{-1}$.
\end{abstract}

Keywords: geomaterials, activated carbon, clay, tetracycline, adsorption

\section{Introduction}

Human development in several fields such as industry and agriculture may have an impact on the economy, and generates colossal amounts of waste that can affect health and the environment, thus causing serious pollution problems. Poorly managed wastes leads to contamination of air, water, and soil. Soil contamination caused by the waste storage may lead to the pollution of groundwater by leakage of landfill leachate [1-8].

Landfill is a complex reactor that spontaneously progress. Therefore, the composition of leachates is very difficult to determine. Despite the complexity of the effluent, it is

\footnotetext{
${ }^{1}$ Scientific and Technical Research Center in Physico-Chemical Analysis, PO box 384, Headquarters ex-Pasna Industrial area Bou-Ismail, zip code 42004 Tipaza, Algeria, phone +213(0)24325774, fax +213(0)24325774, ORCID: 0000-0002-1432-7237

${ }^{2}$ LPCEMAE Laboratory, Faculty of Chemistry, Houari Boumediene University of Science and Technology (USTHB), PO box 32 ELALIA, Bab Ezzouar Algiers, Algeria, email: bhamdi_99@yahoo.fr, ORCID: 0000-0002-5502-1605

${ }^{3}$ Controlled Porosity Materials Team, Institute of Materials Sciences of Mulhouse UMRCNRS 7361, University of Strasbourg, University of Haute Alsace, ENSCMu, 3 rue Alfred Werner, 68093 Mulhouse Cedex, France, email: jocelyne.brendle@uha.fr, ORCID: 0000-0001-5266-6224

*Corresponding author: souh_ait@yahoo.fr
} 
possible to identify these xenobiotic compounds [9-16]: phenols, chlorinated aliphatic compounds, aromatic hydrocarbons, tetracycline, pesticides, and plasticizers.

Among compounds detected in leachates are antibiotics. These compounds were used to treat infectious diseases for human and animals, their consumption has considerably increased in recent years to avoid bacterial infections of susceptible individuals, and used as growth factor for farm animals [17-22]. Antibiotics were roughly transformed in the body of human and animal after administered and released mainly through the urine, and in saddles, through either the parent molecule or metabolites (derived molecule from the processing of the parent molecule into the body by oxidation or conjugation).

The municipal effluents charged with these molecules were purified in sewage plants then released into surface waters (stream, sea). Part of the residue was kept in the sludge and then deposited on the soil, these residues were widespread. In the case of an individual purification system, the groundwater is the main receiving environment [18, 23-30].

Inappropriate and unjustified use of antibiotics leads to the development of resistant bacterial strains making the antibiotic ineffective [31-37]. Thus, the tetracycline was selected, due to its potential to reach soil and the aquatic environment [38-42]. Tetracycline residues were commonly detected on the soil [43-46], sediments [47-50], surface water [51-53], in the groundwater [54-57], wastewater [58-63].

The removal of antibiotics from water and wastewater was carried out by several technological methods, such as photocatalysis, electrocoagulation, and adsorption [24, 64-67]. Adsorption is the most efficient and low cost method for waste treatment. Various materials were used in the adsorption of tetracycline such as: smectite [68-70], montmorillonite [18, 69, 71-74], rectorite [75-78], palygorskite [69, 79-82], chitosan particles [83-86], aluminium oxide [87-90], coal humic acid [26, 91, 92], activated carbon [93-96], single-walled carbon nanotubes, and multiwalled carbon nanotubes. These materials are widely investigated [23, 97-99].

The demand is still increasing to develop effective treatment technologies for the removal of pollutants. Technical landfills are intended for storage of ultimate waste while minimizing risks of pollution and environmental contamination. Isolation of the pollution source from the external environment requires the implementation of landfill sites. The aim of this study was to develop efficient composite geomaterials to remove persistent organic pollutants. The GM composite geomaterial was synthesised from Algerian Na-clay (Maghnia deposit), activated carbon produced from coconut shell, portland cement, and polyvinyl alcohol (PVA) polymer [100]. These constituents were selected based on the sorption properties of clay, activated carbon, and cement, on the mechanical properties related to clay and cement [101-103]. The addition of the polymer improves the sealing and the lifespan of the synthesised composite material. The adsorption capacities of GM and its mineral constituents were tested by adsorption of tetracycline. This study was performed to investigate the synergistic effect of clay and activated carbon on the retention of tetracycline in aqueous solution and to compare the properties of the composite to those of the pristine constituents. The composite developed in this study was intended for waste containment. It was used as a geomembrane and as a passive safety barrier. It was noticed that the composite material was low cost since the major constituent was bentonite. 


\section{Materials and methods}

\section{Materials}

Tetracycline hydrochloride $\mathrm{C}_{22} \mathrm{H}_{24} \mathrm{~N}_{2} \mathrm{O}_{8} \quad \mathrm{HCl}$ (Fig. 1a) was provided by Sigma-Aldrich. Bentonite ATMa was obtained from the deposit of Hamamboughrara (Maghnia) mainly contains montmorillonite, kaolinite, quartz, and calcite in its raw form; it is located in the west of Algeria. The activated carbon is made from coconut shell purchased from Merck. The Portland cement used in this synthesis is from Chlef (west of Algeria), the polyvinyl alcohol (PVA) polymer was purchased from Fluka.

a)

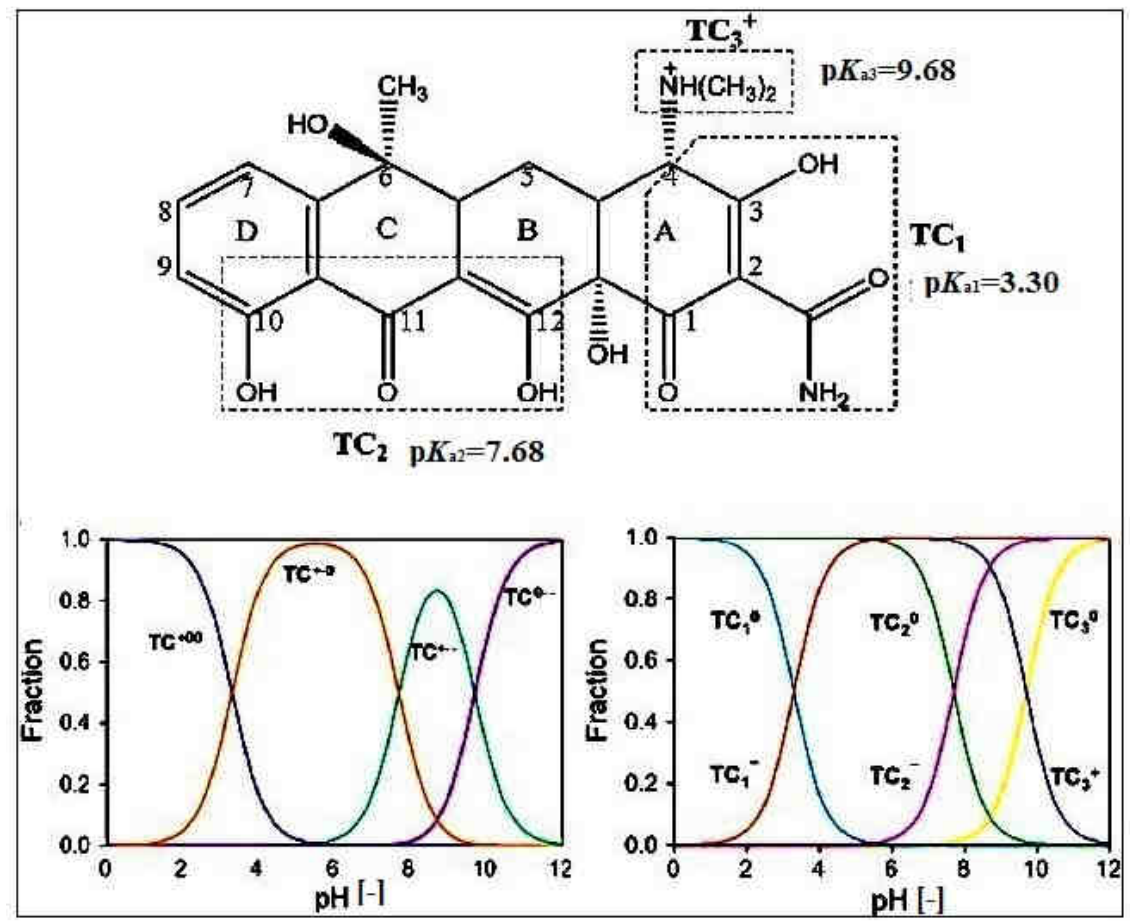

b)

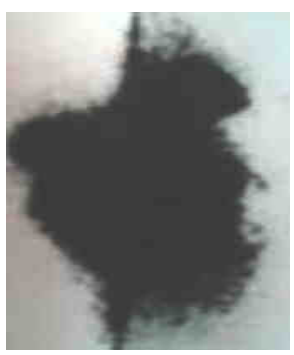

Fig. 1. a) The molecular structure of TC seen in the plane represents functional groups and $\mathrm{pH}$ dependent speciation of tetracycline, b) representative picture of GM geomaterial powder 


\section{Synthesis}

The synthesis of GM material consists of two steps: Purification of clay and mixing of GM constituents. The purification of the raw clay by sedimentation was carried out to separate the montmorillonite from the associated materials (quartz, feldspaths), and to remove these associated minerals according to a method used in a previous study [100]. The GM constituents were mixed with the following weight percentages: Purified clay treated with $\mathrm{NaCl}(80$ wt. \%), activated carbon (5 wt. \%), cement (10 wt. \%) and PVA (5 wt. \%). These materials were mixed with $0.1 \mathrm{dm}^{3}$ of distilled water. The mixture was under constant stirring for 48 hours, then centrifuged. The obtained solid was dried at the room temperature, and was crushed and sieved to obtain a geomaterial $<2 \mu \mathrm{m}$ (Fig. 1b). Ait Hamoudi et al. [100] synthesised three geomaterials used to remove lead. In this study, GM is selected based on its ability to remove $\mathrm{Pb}^{2+}$ compared to the other two geomaterials.

\section{Characterizations}

\section{$\mathrm{N}_{2}$ Adsorption-desorption}

The specific surface areas of samples were measured by the BET method [104-106]. Adsorption-desorption isotherms of nitrogen were measured with a micromeritics ASAP 2024 instrument at 77 K. Samples were degassed for 15 hours at $423 \mathrm{~K}$.

\section{$X$-Ray diffraction $(X R D)$}

After GM and ATMa contact with TC, the XRD patterns were recorded on an X-pert pro panalytical diffractometer with copper radiation $(\lambda=0.15418 \mathrm{~nm})$. The scanning step was $0.02^{\circ} 2 \theta$ over the angular range of $1-70^{\circ} 2 \theta$.

\section{Fourier Transformed Infrared Spectroscopy (FTIR)}

Spectra were carried out in transmission with a Bruker Equinox 55 FT-IR spectrophotometer. Samples were analysed in the form of $\mathrm{KBr}$ pellets of $0.2 \mathrm{~mm}$ thick ( $2 \% \mathrm{w} / \mathrm{w}$ samples). The obtained pellets were analysed by a DTGS detector (deuterated triglycine sulphate). Infrared Spectroscopy spectra were recorded in a 4000-400 $\mathrm{cm}^{-1}$ wavenumber range.

\section{Scanning Electron Microscopy (SEM)}

SEM analysis provides an examination of the sample surface to nanometric scales. The Philips XL-30 FEG scanning electron microscope was used for the analysis. As a preparation step, the sample was covered with gold for a few seconds with the presence of argon gas in order to prevent electrical load.

\section{UV spectroscopy}

The TC concentration was determined by a UV-Vis method with a Perkin Elmer Lambda 35 spectrophotometer at a detection wavelength of $357 \mathrm{~nm}$. An optical quartz cell was used in a thickness of $1 \mathrm{~cm}$. 


\section{Adsorption experiments}

\section{Adsorption kinetics}

The adsorption kinetic was studied to identify the equilibrium time, experiments were carried out, the contact times were $0.5 ; 1 ; 1.30 ; 2 ; 3 ; 4,5 ; 6 ; 7 ; 8 ; 16$ and $24 \mathrm{~h}$, and were conducted at $298 \mathrm{~K}, 0.3 \mathrm{~g}$ of solids (geomaterial, clay, or activated carbon) were placed into $0.05 \mathrm{dm}^{3}$ of tetracycline aqueous solution $\left([\mathrm{C}]=100 \mathrm{mg} \cdot \mathrm{dm}^{-3}\right)$ at $\mathrm{pH} 3(\mathrm{pH}$ of tetracycline solution, without adjustment). Samples were taken from separate bottles, and at the desired contact time after stirring, the suspensions were centrifuged for $20 \mathrm{~min}$ to separate liquid from solid. Sample was filtered and the supernatant was analysed by UV-Vis, each analysis was repeated three times. The following equation was used to determine the tetracycline adsorbed amount onto solids:

$$
Q_{t}=\frac{V\left(C_{0}-C_{e}\right)}{m}
$$

where $Q_{t}$ is the adsorption capacity $\left[\mathrm{mg} \cdot \mathrm{g}^{-1}\right.$ ] of TC on studied materials at equilibrium time $(t), C_{0}$ is the initial tetracycline concentration $\left[\mathrm{mg} \cdot \mathrm{dm}^{-3}\right], C_{e}$ is the residual concentration of TC $\left[\mathrm{mg} \cdot \mathrm{dm}^{-3}\right], V$ is the aqueous solution volume $\left[\mathrm{dm}^{3}\right]$ and $m$ is the mass of adsorbents [g].

\section{Adsorption isotherms}

The adsorption isotherm describes the adsorbed tetracycline amount as a function of residual concentration, it was determined under the same experimental conditions as for adsorption kinetic ( $\mathrm{pH}=3$ and same stirring rate), with different concentrations of tetracycline solutions $\left([\mathrm{C}]=25,50,100,150,200,300,400,500,600,700,800 \mathrm{mg} \cdot \mathrm{dm}^{-3}\right)$, put in contact with an adsorbent amount of $0.3 \mathrm{~g}$ and for a time of $24 \mathrm{~h}$.

pH effect

The $\mathrm{pH}$ effect was investigated; $100 \mathrm{mg} \cdot \mathrm{dm}^{-3}$ of tetracycline solutions were prepared in the $\mathrm{pH}$ range (2-12). After adjustment, the solutions were mixed with $0.3 \mathrm{~g}$ of adsorbent during $24 \mathrm{~h}$ at $298 \mathrm{~K}$. The $\mathrm{pH}$ was adjusted by using $0.1 \mathrm{~N}$ of $\mathrm{HCl}$ or $\mathrm{KOH}$ according to the desired $\mathrm{pH}$ value. The solution $\mathrm{pH}$ values were measured using $\mathrm{pH}$-meter HANNA provided with an electrode of glass. The $\mathrm{pH}$-meter was calibrated with three buffers of $\mathrm{pH}$ 4.0, 7.0, and 10.00. After $24 \mathrm{~h}$, suspensions were filtered and pollutant concentrations in each sample were determined.

\section{Temperature effect}

In order to determine the thermodynamic parameters, adsorption experiments were performed for: activated carbon, ATMa, and GM, at 298, 308, and $318 \mathrm{~K}$ at concentrations of $25,50,100,150,200,300,400,500,600,700,800 \mathrm{mg} \cdot \mathrm{dm}^{-3}$, under the same experimental conditions as those used in adsorption isotherms at $298 \mathrm{~K}$ (pH of solution $(\mathrm{pH}=3))$. Experiments were carried out in a thermostated bath.

\section{The modelling adsorption kinetics}

To assess the adsorption rate of TC on clay, activated carbon, and GM. The rate equations of the pseudo-first-order, pseudo-second-order and intraparticle diffusion models were applied to understand the experimental data. 


\section{Pseudo-first-order model}

It was assumed that the sorption rate at a time $t$ is proportional to the difference between the adsorbed amount at equilibrium $\left(q_{e}\right)$ and that adsorbed at time $t\left(q_{t}\right)$. The adsorption rate law was given by:

$$
\frac{d q_{t}}{d t}=k_{1}\left(q_{e}-q_{t}\right)
$$

After integration with the initial condition $q_{t}=0$ at $t=0$, the following equation can be obtained:

$$
\log \left(q_{e}-q_{t}\right)=\log q_{e}-\frac{k_{1} t}{2.303}
$$

where $q_{t}$ is the adsorption capacity at time $t\left[\mathrm{mg} \cdot \mathrm{g}^{-1}\right]$ and $k_{1}\left[\mathrm{~min}^{-1}\right]$ is the pseudo-first-order adsorption rate constant was given by the linear form of this model (Eq. (3)). The Ho's second-order rate equation can be expressed as [11]:

$$
\frac{t}{q_{t}}=\frac{1}{k_{2} q_{e}^{2}}+\frac{1}{q_{e}} t
$$

where $k_{2}\left[\mathrm{~g} \cdot \mathrm{mg}^{-1} \cdot \mathrm{min}^{-1}\right]$ is the pseudo-second-order adsorption rate constant. Values of $k_{2}$ and $q_{2}$ can be calculated from the plot of $t / q_{t}$ against $t$.

In the intraparticle diffusion model $[107,108]$, the relationship between $q_{t}$ and $t^{0.5}$ could be written as:

$$
q_{t}=k_{3} t^{0.5}+C
$$

where $k_{3}\left[\mathrm{mg} \cdot \mathrm{g}^{-1} \cdot \min ^{0.5}\right]$ is the intraparticle diffusion rate. And $C$ is the intercept of the line that is proportional to the boundary layer thickness.

\section{The modelling adsorption isotherms}

The results of tetracycline adsorption throughout the concentration range were fitted according to the isotherm equations of the Freundlich [109, 110], and the Langmuir [111, 112] models, by using Eqs. (6) and (7) respectively:

$$
\begin{aligned}
\log Q_{a} & =\log K_{F}+\frac{1}{n} \log C_{e} \\
\frac{C_{e}}{Q_{a}} & =\frac{1}{Q_{m}} C_{e}+\frac{1}{K_{L} Q_{m}}
\end{aligned}
$$

where $Q_{a}$ is the adsorbed amount given in $\left[\mathrm{mg} \cdot \mathrm{g}^{-1}\right], C_{e}\left[\mathrm{mg} \cdot \mathrm{dm}^{-3}\right] . K_{F}$ and $n$ are the Freundlich constants related to the adsorption capacity and the adsorption intensity, respectively and $K_{L}\left[\mathrm{dm}^{3} \cdot \mathrm{mg}^{-1}\right]$ is a coefficient assigned to the affinity between the adsorbent and the adsorbate [113, 114].

\section{Thermodynamic parameters}

The Gibbs free energy is a thermodynamic quantity that may inform about the spontaneity of the system. Gibbs free energy $\left(\Delta G^{\circ}\right)$ can be obtained by the following equation $[115,116]$ :

$$
\Delta G^{\circ}=-\mathrm{R} T \ln K_{d}
$$

where $\mathrm{R}$ is the gas constant $\left(\mathrm{R}=8.314 \mathrm{~J} \cdot \mathrm{mol}^{-1} \cdot \mathrm{K}^{-1}\right)$. 
The thermodynamic parameters were calculated from the following equation:

$$
K_{d}=\frac{q_{e}}{C_{e}}
$$

The plot of $\ln K_{d}$ as a function of $1 / \mathrm{T}$ determined the thermodynamic parameters, by the slope and the $y$-intercept, that are: $-\frac{\Delta H^{\circ}}{\mathrm{R}}$ and $\frac{\Delta S^{\circ}}{\mathrm{R}}$, respectively.

\section{Results and discussion}

\section{$\mathrm{N}_{2}$ adsorption-desorption}

The adsorption-desorption isotherm of $\mathrm{N}_{2}$ for the studied adsorbents were displayed in Figure 2.

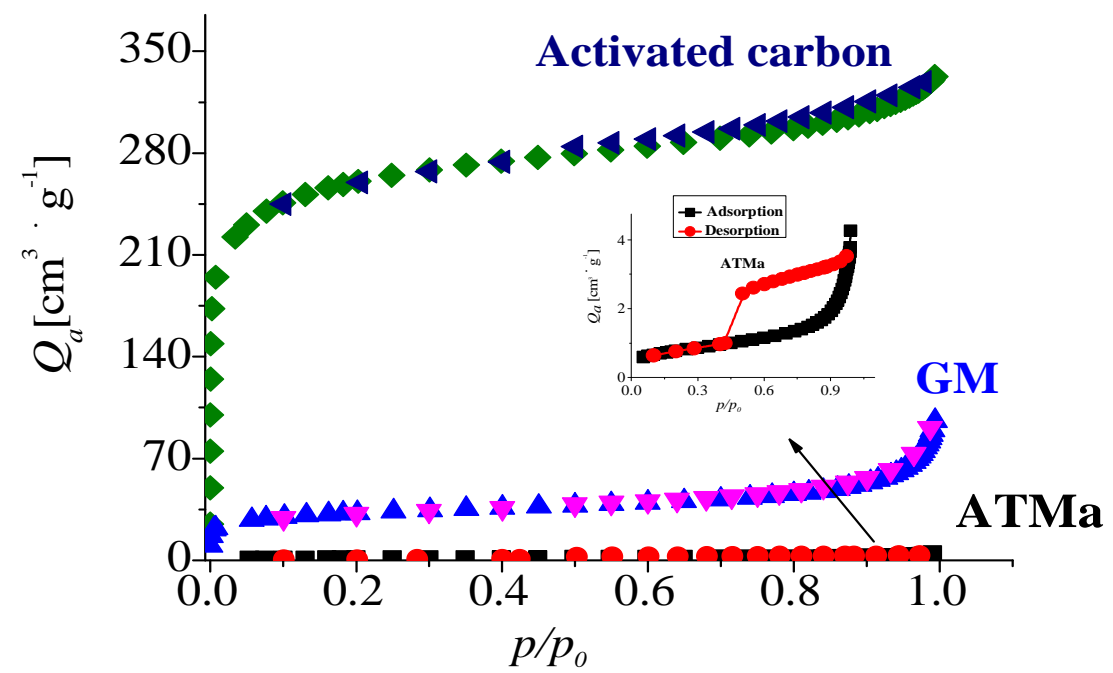

Fig. 2. $\mathrm{N}_{2}$ adsorption-desorption isotherms onto studied adsorbents: activated carbon, GM and ATMa samples

It was observed in Figure 2 that the adsorption isotherms are of type IV with hysteresis loops of type H3 for GM and ATMa samples according to the IUPAC classification. Type IV isotherms are obtained for mesoporous materials $(2 \mathrm{~nm}<$ pore size $<50 \mathrm{~nm}$ ). Hysteresis loops were observed at high pressures, it can be summarized that adsorption and desorption do not occur in the same way [117-119].

On the GM isotherm (Fig. 2), significant adsorption at low pressure is noticed, due to the presence of the micropores. H3 hysteresis is usually connected with a wide size distribution materials and with plate-shaped particle aggregates that gave rise to the slit-shaped pores [120]. Such pores arise as the solid is composed mainly of plate-shaped particles or layer structure that is characteristic of clay structure, due to capillary condensation [120-123] (Fig. 2). This microporosity was due to the addition of activated carbon to the bentonite. 
Source of reagents, textural characteristics and $C E C$, particle size and water content of GM and its constituents

\begin{tabular}{|c|c|c|c|c|c|c|}
\hline Materials & Source & $\begin{array}{c}\boldsymbol{S}_{\boldsymbol{B E T}}{ }^{*} \\
{\left[\mathbf{N}_{2} / \mathbf{7 7} \mathbf{~ K}\right]}\end{array}$ & $\begin{array}{c}\boldsymbol{V}_{\boldsymbol{p}}^{* *} \\
{\left[\mathbf{c m}^{3} \cdot \mathbf{g}^{-\mathbf{1}}\right]}\end{array}$ & $\begin{array}{c}\boldsymbol{C E C} \boldsymbol{C}^{* * * *} \\
{[\mathbf{m e q} / \mathbf{1 0 0} \mathbf{g}]}\end{array}$ & $\begin{array}{c}\text { Particle size } \\
{[\boldsymbol{\mu \mathbf { m } ]}]}\end{array}$ & $\begin{array}{c}\text { Water content } \\
{[\%]}\end{array}$ \\
\hline Bentonite & Maghnia & 90 & 0.12 & 86.5 & $<2$ & 9 \\
\hline GM & Synthesised & 115 & 0.14 & 63.50 & $<2$ & 2.5 \\
\hline $\begin{array}{c}\text { Activated } \\
\text { carbon }\end{array}$ & Coconut & 950 & 0.35 & - & $<20$ & 7.8 \\
\hline
\end{tabular}

*- Specific surface area, ${ }^{* *}$ - Pore volume, ${ }^{* * *}$ - Cation exchange capacity

The adsorption-desorption isotherm of $\mathrm{N}_{2}$ on activated carbon is of type I and it does not show a characteristic hysteresis loop of mesopores. The specific surface areas $\left(S_{B E T}\right)$ of the studied materials were calculated using the BET equation. The physicochemical properties of the investigated materials were gathered in Table 1.

\section{SEM analysis}

Changes in clay morphology were investigated by Scanning Electron Microscopy (SEM). SEM images were observed in Figure 3. The clay in pristine structure represents a regular and smooth surface where large lamellae tend to form large agglomerates with layered arrangement (Fig. 3a). In Figure 3b, it is noticed that the surface of the sample is rougher than that of the ATMa sample. This is attributed to the activated carbon and the PVA polymer that are deposited on the clay layers during the synthesis of GM.

a)

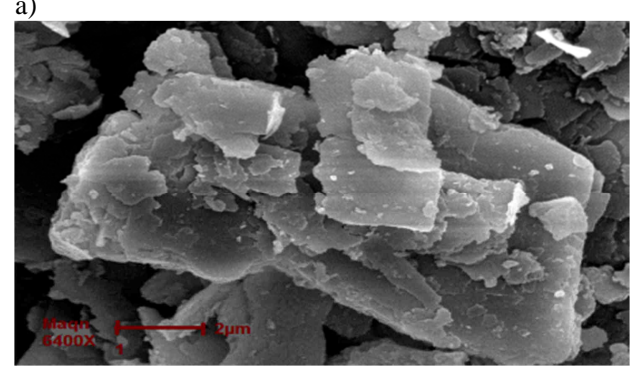

b)

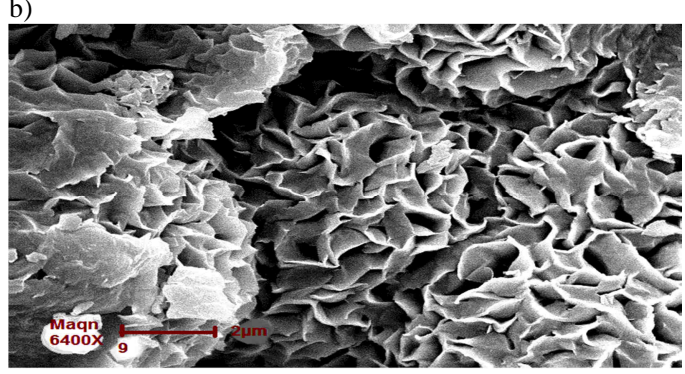

Fig. 3. SEM images of: a) ATMa, b) GM

\section{Tetracycline adsorption}

\section{Adsorption kinetics}

In this section, the adsorption process was studied. Samples were analysed by UV-visible spectroscopy. The UV-visible absorption spectrum of tetracycline was displayed in Figure 4a. Two absorption wavelengths were noticed at $\lambda=275$ and $375 \mathrm{~nm}$. Sample analysis was performed at $\lambda=375 \mathrm{~nm}$. The adsorption kinetic result of $\mathrm{TC}$ on ATMa, activated carbon, and GM samples was shown in Figure 4b. 
a)

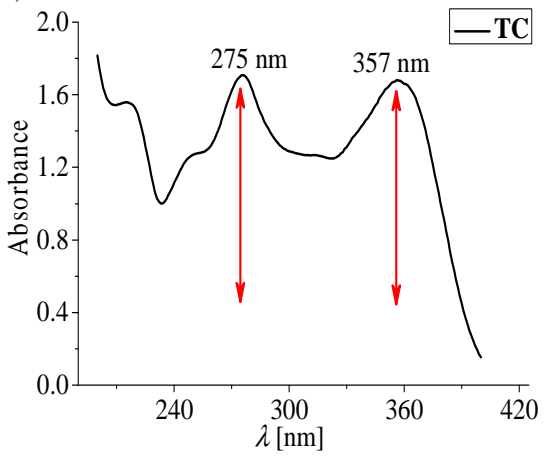

b)

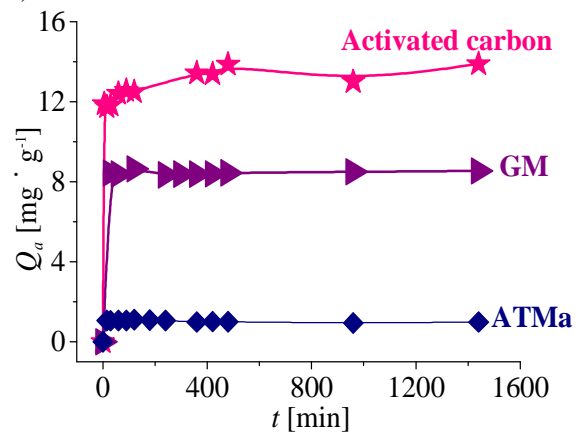

Fig. 4. a) Tetracycline UV-Vis absorption spectra, b) adsorption kinetic of tetracycline on ATMa, activated carbon and GM samples

In Figure $4 b$, it is observed that the adsorption kinetic of ATMa and GM were fast during the first 10 minutes. The adsorbed amount increased to reach a plateau after $30 \mathrm{~min}$. This indicates that equilibrium was reached. The adsorption kinetic proceeded in two stages [79, 124-126]:

- $\quad$ 1st step: The TC molecule was slowly diffused into the clay intermediate layers.

- 2nd step: In this second step, the tetracycline was fastly adsorbed onto the clay surface.

Equilibrium time of activated carbon was set to $60 \mathrm{~min}$. The adsorbed amount of tetracycline was $13.89,8.55$ and $0.99 \mathrm{mg} \cdot \mathrm{g}^{-1}$, onto activated carbon, GM and ATMa, respectively (activated carbon $>\mathrm{GM}>>\mathrm{ATMa}$ ).

\section{Adsorption kinetic models}

In order to investigate the mechanism of tetracycline adsorption, the adsorption kinetics of TC-adsorbent systems were modelled by pseudo-first-order, pseudo-second-order and intraparticle diffusion kinetic models. The mathematical expressions were given by (3), (4) and (5) equations, respectively. All kinetic parameters were determined on the basis of the intercept and the slope for respective plots, were summarized in Tables 2, 3, and 4. The agreement between the measured and calculated data was evaluated. The normalized standard deviation $\Delta q[\%]$ was used, the expression is determined as:

$$
\Delta q=100 \sqrt{\sum \frac{\left[\left(q_{\text {exp }}-q_{\text {cal }}\right) / q_{\text {exp }}\right]^{2}}{(n-1)}}
$$

where the subscripts 'exp' and 'cal' are the experimental and calculated values, respectively, and $n$ is the number of data points.

The results gathered in Table 2 revealed that the pseudo-second-order model fitted well the adsorption kinetics data. This was confirmed by the correlation coefficient $R^{2}$. The $\left(q_{e}\right)$ values of the adsorbed amounts were determined by the pseudo-second-order kinetic model were in a good agreement with those of experimental data, in contrast to the pseudo-first-order model that is not in coherence with the experimental data (Table 2). 
The pseudo-first- and second-order model rate constants kinetic model parameters of tetracycline adsorption on investigated adsorbents

\begin{tabular}{|c|c|c|c|c|c|c|c|c|}
\hline Models & \multicolumn{4}{|c|}{$\begin{array}{c}\text { Pseudo-first-order } \\
\text { (Lagergren) }\end{array}$} & \multicolumn{3}{c|}{ Pseudo-second-order } \\
\hline Adsorbents & $\begin{array}{c}q_{e} \\
{\left[\mathrm{mg}^{-1} \mathrm{~g}^{-1}\right]}\end{array}$ & $\begin{array}{c}K_{1} \\
{\left[\mathrm{~min}^{-1}\right]}\end{array}$ & $\begin{array}{c}R^{2} \\
{[-]}\end{array}$ & $\begin{array}{c}\Delta q \\
{[\%]}\end{array}$ & $\begin{array}{c}q_{e} \\
{\left[\mathrm{mg} \cdot \mathrm{g}^{-1}\right]}\end{array}$ & $\begin{array}{c}K_{2} \\
{\left[\mathrm{~g} \cdot \mathrm{mg} \cdot \mathrm{min}^{-1}\right]}\end{array}$ & $\begin{array}{c}R^{2} \\
{[-]}\end{array}$ & $\begin{array}{c}\Delta q \\
{[\%]}\end{array}$ \\
\hline GM & 0.92 & $87.10^{-4}$ & 0.3602 & 127.70 & 8.47 & 0.0326 & 0.9999 & 21.10 \\
\hline $\begin{array}{c}\text { Activated } \\
\text { carbon }\end{array}$ & 1.84 & $122.10^{-4}$ & 0.5505 & 128.45 & 13.51 & 0.0077 & 0.9983 & 3.98 \\
\hline ATMa & 0.19 & $11.10^{-4}$ & 0.0179 & 131.51 & 0.97 & -0.115 & 0.9986 & 38.38 \\
\hline
\end{tabular}

The plot of $q_{t}$ as a function of $t^{0.5}$, exhibits multiple linearity which indicate that the whole adsorption process occurs in two or more stages. The intra-particle diffusion curve was evaluated, it was noticed that the adsorption of tetracycline was produced in two or three distinct stages. The first stage was assigned to the diffusion of tetracycline onto the outer surface of adsorbents in the solution. The second phase was the intra-particle diffusion of $\mathrm{TC}$ in the investigated material pores. The third phase is assigned to the intraparticle diffusion of TC molecules toward the adsorption sites in pores.

Table 3

The intraparticle model rate constants kinetic model parameters of tetracycline adsorption on GM and activated carbon

\begin{tabular}{|c|c|c|c|c|c|c|c|c|}
\hline Adsorbents & \multicolumn{4}{|c|}{ GM } & \multicolumn{4}{c|}{ Activated carbon } \\
\hline Parameters & Step1 & Step2 & Step3 & Step4 & Step1 & Step2 & Step3 & Step4 \\
\hline$R^{2}[-]$ & - & - & 0.80 & - & - & 0.93 & 0.83 & - \\
\hline $\begin{array}{c}K_{\text {dintr }} \\
{\left[\mathrm{mg} \cdot \mathrm{g}^{-1} \cdot \min ^{0.5}\right]}\end{array}$ & 1.54 & 0.081 & 0.013 & 0.007 & 5.31 & 0.15 & 0.12 & 0.10 \\
\hline$C[-]$ & 0 & 7.76 & 8.15 & 8.27 & 0 & 11.24 & 10.43 & 9.01 \\
\hline$\Delta q[\%]$ & 295.52 & 13.16 & 1.68 & 1.25 & 671.72 & 9.94 & 7.23 & 18.18 \\
\hline
\end{tabular}

Table 4

The intraparticle model rate constants kinetic model parameters of tetracycline adsorption on ATMa clay

\begin{tabular}{|c|c|c|c|c|}
\hline Adsorbents & \multicolumn{4}{|c|}{ ATMa } \\
\hline Parameters & Step1 & Step2 & Step3 & Step4 \\
\hline$R^{2}[-]$ & - & 0.0857 & 0.4637 & - \\
\hline$K_{\text {dintr }}\left[\mathrm{mg} \cdot \mathrm{g}^{-1} \cdot \mathrm{min}^{0.5}\right]$ & 0.27 & 0.007 & 0.003 & 0.001 \\
\hline$C[-]$ & 0 & 1.05 & 0 & 0.71 \\
\hline$\Delta q[\%]$ & 346.41 & 14.41 & 91.69 & 29.96 \\
\hline
\end{tabular}

The rate constants and $C$ (intercept) were obtained from the plot $q_{t}$ versus $t^{0.5}$ and results were gathered in Tables 3 and 4 . The rate constant values were compared, it was noted that the $K_{\text {dintr }}$ of the final step is lower than that of the other diffusion steps. This result indicated that the rate which limits the TC adsorption process is intraparticle diffusion that corresponds to the final stage of equilibrium, where the concentration of the solute in the solution is low. However, the intraparticle diffusion model is not the only mechanism that determines the rate constant [127-131], since there are lines on the curve $q_{t}$ as a function of $(t)^{0.5}$ that do not pass through the origin (Figure not shown). Therefore, the adsorption of TC on the studied adsorbents is seen as a complex process of both intraparticle diffusion and surface sorption which contribute to the rate limiting step [129, 132-135]. 
Straight lines that pass through the origin may be due to the difference in mass transfer rate in the initial stage of adsorption. Furthermore, the intercept provides information on the thickness of the boundary layer, the larger the intercept, the greater the effect of the boundary layer [127, 136-138].

\section{pH effect on tetracycline adsorption}

The $\mathrm{pH}$ effect of the tetracycline adsorption onto GM was illustrated in Figure 5a. It was noted that the tetracycline adsorption on GM demonstrated strong $\mathrm{pH}$ dependence from $\mathrm{pH} 2$ to $\mathrm{pH} 12$.

a)

b)

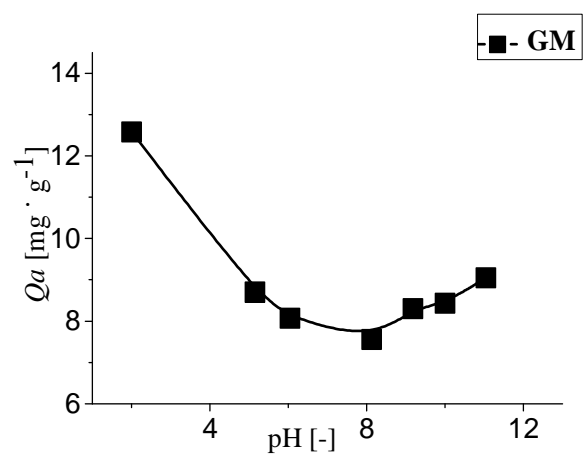

$\mathrm{TCH}_{2}^{ \pm}$

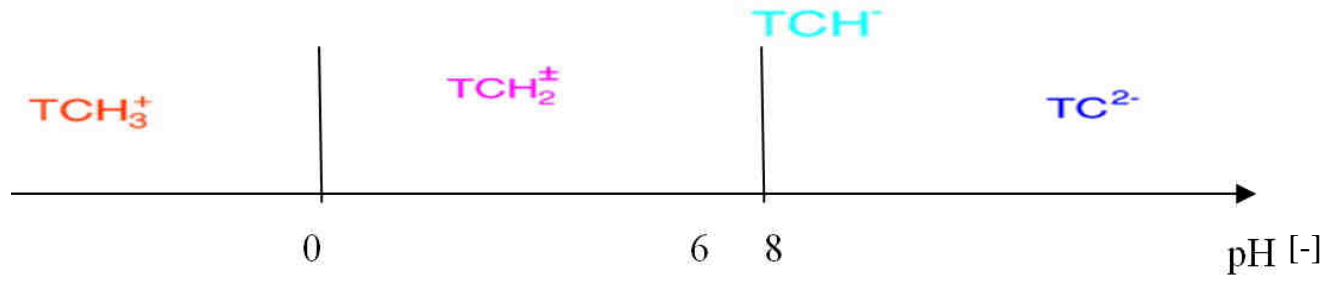

Fig. 5. a) $\mathrm{pH}$ effect of tetracycline adsorption on $\mathrm{GM}$ at $[\mathrm{C}]=100 \mathrm{mg} \cdot \mathrm{dm}^{-3}$ and $\mathrm{T}=298 \mathrm{~K}$,

b) $\mathrm{pH}$-dependent speciation of the whole TC molecular according to Zhang et al. [50]

In Figure 5a it was observed that the adsorbed amount is maximum at $\mathrm{pH}=2$ $\left(Q_{a}=12.6 \mathrm{mg} \cdot \mathrm{g}^{-1}\right)$, at $\mathrm{pH}=8 Q_{a}$ decreased until it reached minimum value $\left(Q_{a} \approx 7.8 \mathrm{mg} \cdot \mathrm{g}^{-1}\right)$ before rising slightly to $\mathrm{pH}=12\left(Q_{a} \approx 9.55 \mathrm{mg} \cdot \mathrm{g}^{-1}\right)$. This is due to the presence of $\mathrm{TCH}_{3}{ }^{+}$species at a highly acidic $\mathrm{pH}$ range (Fig. 5b). Hence, strong cation exchange interactions took place. At $\mathrm{pH}=8$, the surface of $\mathrm{GM}$ was negatively charged and the $\mathrm{TCH}^{-}$species was present at this $\mathrm{pH}$ value, which caused electrostatic repulsion between the surface of $\mathrm{GM}$ and the $\mathrm{TCH}^{-}$species. Therefore, the decrease in the adsorbed amount $\left(Q_{a}\right)$, this decrease is also due to the steric hindrance of $\mathrm{TCH}^{2+}$ and $\mathrm{TCH}^{-}$that coexisted at $\mathrm{pH}=8$, at $\mathrm{pH}>8, \mathrm{Ca}^{2+}$ that comes from the cement and the TC molecule form a complex (chelate) [139-142]. The negative charge that occurs from $\mathrm{TC}^{2-}$ groups was neutralized and yields a net positive charge of TC molecule. Therefore the adsorption was enhanced [142-144]. 


\section{Adsorption isotherms}

The adsorption isotherm of TC onto the investigated adsorbents was carried out at $298 \mathrm{~K}$ and at $\mathrm{pH}=3$ ( $\mathrm{pH}$ of the solution). In Figure 6a were illustrated the adsorption isotherm curves.

A high affinity of TC for activated carbon was observed. This was interpreted by a significant adsorbed amount $\left(Q_{a}=157.24 \mathrm{mg} \cdot \mathrm{g}^{-1}\right)$ and a low residual concentration $\left(C_{e}=13.76 \mathrm{mg} \cdot \mathrm{dm}^{-3}\right)$ as it was shown in Figure $6 \mathrm{a}$, and the adsorption capacity of tetracycline onto GM is $75.5 \mathrm{mg} \cdot \mathrm{g}^{-1}$ and the residual concentration of $347.03 \mathrm{mg} \cdot \mathrm{dm}^{-3}$ for a solution initial concentration of $C_{0}=800 \mathrm{mg} \cdot \mathrm{dm}^{-3}$.

From the Figure $6 \mathrm{a}$, it was noted that the tetracycline is well adsorbed onto GM compared to ATMa clay, as confirmed by clay adsorbed amount of $9.65 \mathrm{mg} \cdot \mathrm{g}^{-1}$.

The majority of antibiotic compounds hold acidic and/or basic functions. Their ionic form is necessary for the adsorption of these compounds onto activated carbon according to Westerhoff et al., and Wang et al. [145, 146]. It appeared that the improvement of the TC adsorption is associated with phenolic functional groups [147]. Thus, several authors [147-149] in their intensive study of organic compound adsorption, proved that the process stays contentious, and noted that the two interactions (adsorbate-adsorbent) electrostatic and dispersive are involved in adsorption of aromatic compounds. However, Coughlin and Ezra, Yi et al., and Cunha et al. [150-152] suggested that the adsorption of aromatic compounds onto activated carbon is based on the establishment of dispersion interactions between $\pi$ electrons in the organic compound aromatic ring and $\pi$ electrons of the activated carbon graphene planes ( $\pi-\pi$ interactions). Moreover, the more intense adsorption capacity of activated carbon was required in part to its weak oxygen content $[153,154]$, thus a rise in its hydrophobicity and the electron density of the graphene planes $[155,156]$. Electrons of the aromatic rings raise the adsorption of $\mathrm{TC}$ as the dispersive interactions $\pi-\pi$ (adsorbate-adsorbent) were progressed [157, 158].

Adsorption of phenolic compounds was considerably affected molecular oxygen [159, 160], and functional groups on the surface of the activated carbon [161, 162].

Molecular oxygen in the aqueous phase promotes chemical treatment such as the oligomerization of organic compounds adsorbed on the surface of the carbon [94, 163-165], that enhances adsorption capacity.

Several studies $[43,73,75,78,166]$, have indicated that the adsorption of TC on pure montmorillonite is related to the cation exchange capacity $(C E C)$. In this study, there is no relationship between the adsorption of TC and CEC. The adsorption of TC on GM depended mainly on the addition of activated carbon to montmorillonite. Therefore, the hydrophobicity induced by activated carbon is greater than the $C E C$ of clay. This is an important factor since it increases the surface area of GM [167-169], the clay is more hydrophobic which yields a great capacity to retain the TC molecule, hence the difference between the adsorbed amount of ATMa clay and GM.

\section{Adsorption isotherm models}

The adsorption isotherms of TC on activated carbon, ATMa clay, and GM were modelled by the Freundlich and Langmuir models. The modelling parameters were gathered in Table 3.

From Table 3, it was indicated that the best correlation coefficients $R^{2}>0.99$ were common for activated carbon, ATMa clay, and GM, were given by the Langmuir model. 
This result confirms that the drug molecules adsorb in a monolayer on the adsorbent surfaces with homogeneity $[170,171]$, the maximum adsorption capacity $\left(q_{m}\right)$ as a fitting model parameter was $156.25,75.18,9.68 \mathrm{mg} \cdot \mathrm{g}^{-1}$, for activated carbon, GM, and ATMa, respectively. It was in a close agreement with the measured data $(157.24,75.5$, $9.65 \mathrm{mg} \cdot \mathrm{g}^{-1}$ ), and $0<R_{L}<1$ which indicates that the adsorption isotherm is favourable. Overall, the Langmuir model fits well. Although the correlation coefficient $R^{2}>0.99$ for the Freundlich model, the parameter $1 / n$ which indicates that the linearity deviation of the adsorption isotherm is greater than 1 and which is not in the range of validity $[0.3 ; 0.5]$ $[44,172]$. The Freundlich model does not fit the data well.

\section{Temperature effect on TC adsorption}

The temperature effect was performed for three temperatures. Namely: 298, 308, and $318 \mathrm{~K}$. The result was illustrated in Figure $6 \mathrm{~b}$. In Figure $6 \mathrm{~b}$, it was noticed that by increasing the temperature the adsorption capacity increases. Therefore, the process was endothermic [173-175].

\section{Adsorption isotherm models}

Data obtained from TC adsorption at 308 and $318 \mathrm{~K}$ were examined by the Freundlich and Langmuir isotherm models. Parameters were collected in Table 5.

In Table 5, it was observed that the $K_{L}$ Langmuir constant increases as temperature increases from 298 to $318 \mathrm{~K}$ for all the studied adsorbents. The $K_{L}$ parameter informs about the binding energy between the adsorbate-adsorbent. The more $K_{L}$ is important the stronger the TC-adsorbent bond. In Table 5, it was also noticed that the Langmuir model fits well the experimental data of the isotherm, with good $R^{2}$ correlation coefficients. Although $R^{2}$ is close to 1 as was indicated in Table 5, Freundlich model does not fit TC adsorption isotherm onto adsorbents, as the value of $1 / n$ is not in the validity range $[0.3 ; 0.5]$ for all investigated temperatures.

Table 5

Parameters studied adsorption isotherms of TC on GM, activated carbon and ATMa at 298, 308 and $318 \mathrm{~K}$

\begin{tabular}{|c|c|c|c|c|c|c|c|c|c|c|}
\hline \multirow{2}{*}{\begin{tabular}{|c|} 
Models \\
$\begin{array}{c}\text { Adsor- } \\
\text { bents }\end{array}$
\end{tabular}} & \multicolumn{4}{|c|}{ Langmuir } & \multicolumn{6}{|c|}{ Freundlich } \\
\hline & $\begin{array}{c}T \\
{[\mathrm{~K}]}\end{array}$ & $\begin{array}{c}Q_{m} \\
{\left[\mathrm{mg} \cdot \mathrm{g}^{-1}\right]}\end{array}$ & $\begin{array}{c}K_{L} \\
{\left[\mathrm{dm}^{3} \cdot \mathrm{mg}^{-1}\right]}\end{array}$ & $\begin{array}{c}\Delta q \\
{[\%]}\end{array}$ & $\begin{array}{l}R_{L} \\
{[-]}\end{array}$ & $\begin{array}{l}R^{2} \\
{[-]}\end{array}$ & $\begin{array}{l}\Delta q \\
{[\%]}\end{array}$ & $\begin{array}{c}K_{F} \\
{\left[\mathrm{dm}^{3} \cdot \mathrm{mg}^{-1}\right]}\end{array}$ & $1 / n$ & $\begin{array}{l}R^{2} \\
{[-]}\end{array}$ \\
\hline \multirow{3}{*}{ GM } & 298 & 75.18 & 0.002 & 30.67 & $0.936-0.316$ & 0.9996 & 1021.44 & 0.122 & 1.06 & 0.9799 \\
\hline & 308 & 100 & 0.55 & 498.5 & $0.067-2.26 \cdot 10^{-3}$ & 0.9992 & 27.62 & $7.67 \cdot 10^{-3}$ & 1.73 & 0.9670 \\
\hline & 318 & 108.69 & 3.68 & 518.64 & $0.01-3.39 \cdot 10^{-4}$ & 0.9989 & 21.28 & $6.49 \cdot 10^{-4}$ & 2.38 & 0.9728 \\
\hline \multirow{3}{*}{$\begin{array}{l}\text { Activated } \\
\text { carbon }\end{array}$} & 298 & 156.25 & 0.007 & 78.24 & $0.843-0.144$ & 0.9989 & 10.23 & 0.028 & 2.84 & 0.9913 \\
\hline & 308 & 158.73 & 0.14 & 62.47 & $0.22-8.84 \cdot 10^{-3}$ & 0.9994 & 145.55 & 66.68 & 0.75 & 0.9400 \\
\hline & 318 & 160 & 0.25 & 54.85 & $0.137-4.97 \cdot 10^{-3}$ & 0.9987 & 25.00 & 64.71 & 1.20 & 0.9807 \\
\hline \multirow{3}{*}{ АTMa } & 298 & 9.68 & 0.023 & 126.22 & $0.634-0.051$ & 0.9994 & 112.17 & 0.08 & 1.48 & 0.9726 \\
\hline & 308 & 9.70 & 4.68 & 1076.14 & $0.096-2.67 \cdot 10^{-4}$ & 0.9993 & 21.55 & 0.10 & 1.46 & 0.9807 \\
\hline & 318 & 9.71 & 4.70 & 1043.98 & $\begin{array}{l}8.43 \cdot 10^{-3}- \\
2.65 \cdot 10^{-4}\end{array}$ & 0.9998 & 78.48 & 0.57 & 0.90 & 0.9634 \\
\hline
\end{tabular}


a)

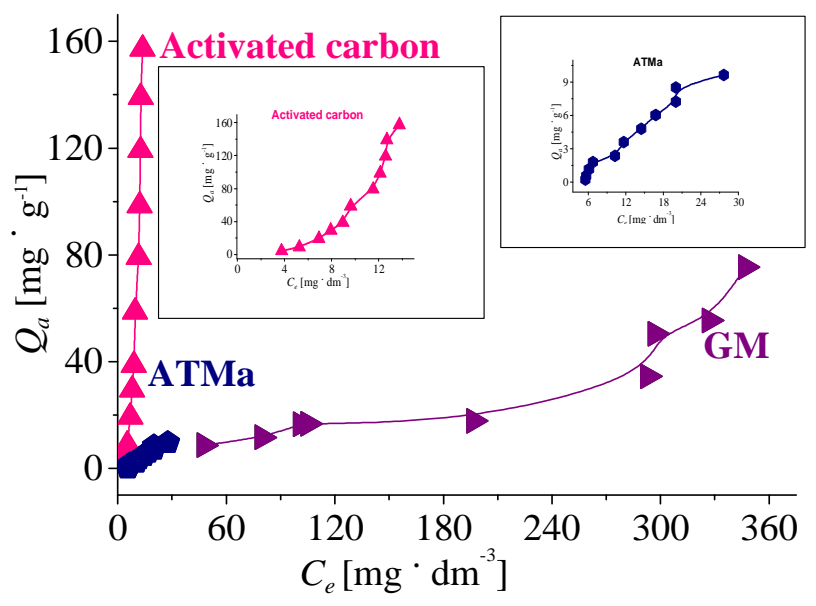

b)

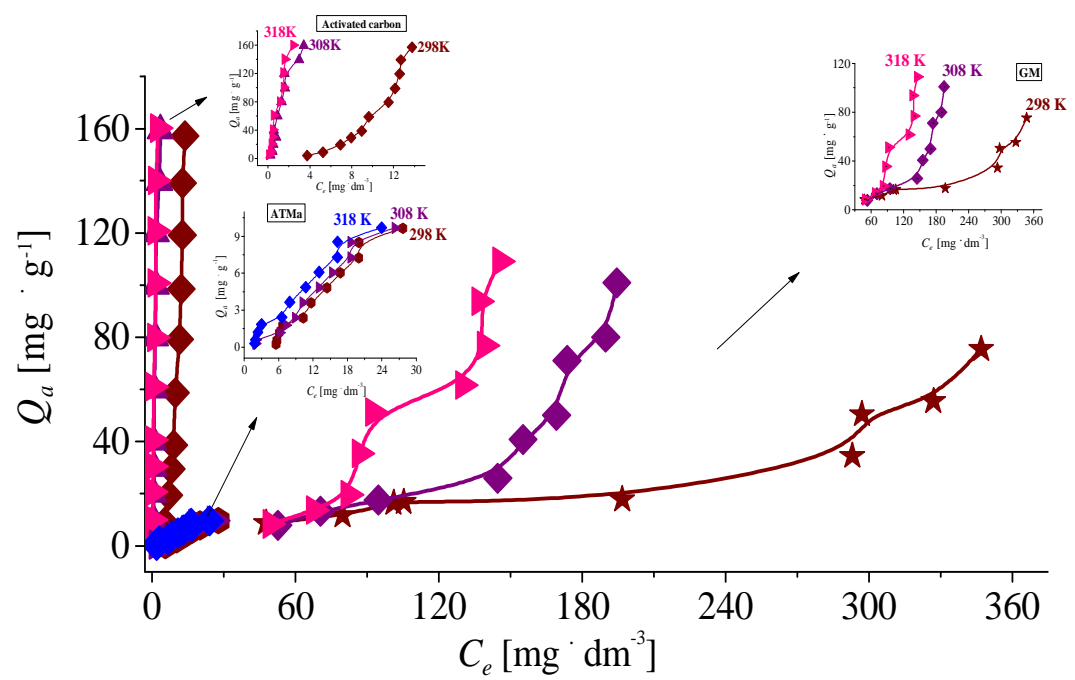

c)

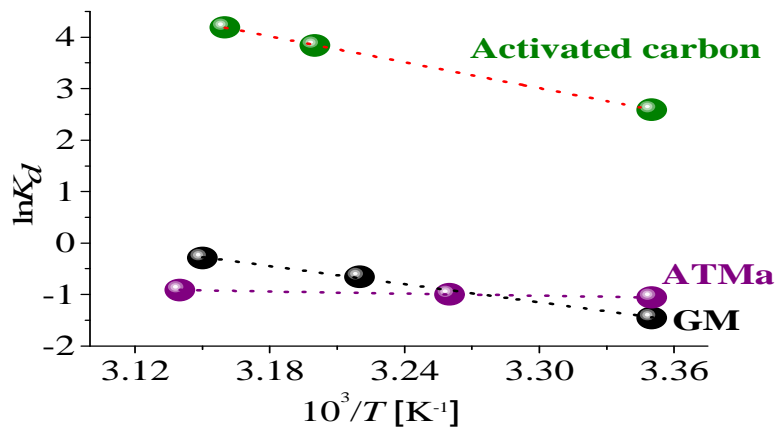

Fig. 6. a) The adsorption isotherms at $298 \mathrm{~K}$ of tetracycline on ATMa, activated carbon and GM samples at solution $\mathrm{pH}=3, \mathrm{~b}$ ) temperature effect on TC adsorption, c) plot of $K_{d}$ as function of $1 / \mathrm{T}$ 


\section{Adsorbents characterization after contact with TC}

\section{XRD method}

To better explain the adsorption mechanism of TC on ATMa and GM, these adsorbents were put in contact with a TC solution of $800 \mathrm{mg} \cdot \mathrm{dm}^{-3}$ for $24 \mathrm{~h}$ and then characterized by X-ray diffraction. The highest reflection intensity was $12.37^{\circ}(2 \theta)$ for ATMa and GM, this reflection was associated with $d_{001}$ spacing of $7.14 \AA$, as observed in Figure 7 .

The reflection position did not change and the $d_{001}$ distance is invariant after contact with TC of $800 \mathrm{mg} \cdot \mathrm{dm}^{-3}$. This behaviour can be explained as the molecule of tetracycline was not adsorbed by intercalation into the interlayer space of the adsorbent structure, but TC was adsorbed on the surface of the clay ATMa and GM $[75,176]$.

a)

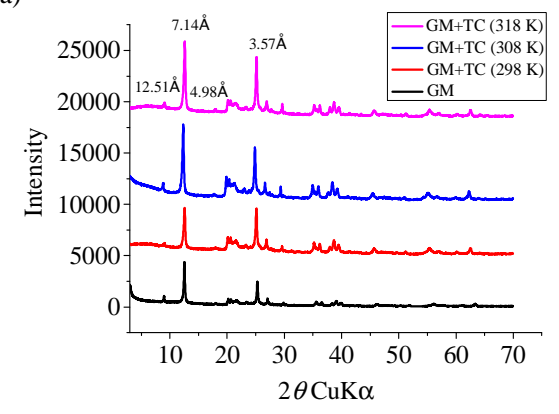

b)

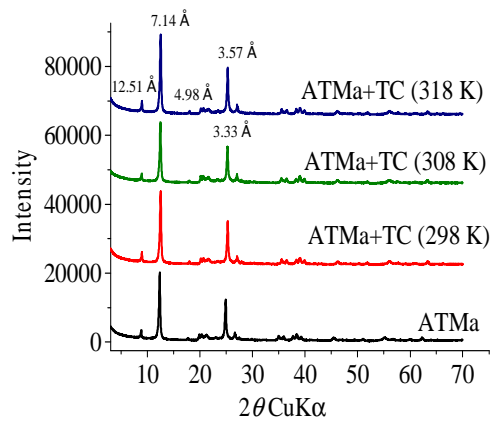

Fig. 7. X-ray spectra of: a) ATMa clay and b) GM after contact with TC at $T: 298,308$ and $318 \mathrm{~K}$

\section{FTIR}

In order to characterize the adsorbents studied contacted with TC solution of $800 \mathrm{mg} \cdot \mathrm{dm}^{-3}$ concentration at temperatures $298,308,318 \mathrm{~K}$, infrared spectroscopy was used (Figure not shown).

The characteristic bands of TC are in the range of $1200-1700 \mathrm{~cm}^{-1}[75,177-179]$. On the infrared spectrum of ATMa-TC it is observed the vibration bands at 1113, 1633, 3527,3394 and $3617 \mathrm{~cm}^{-1}$. The band at $1113 \mathrm{~cm}^{-1}$ was attributed to the stretching vibration of Si-O. The band at $1633 \mathrm{~cm}^{-1}$ is assigned to the stretching vibration at ring $\mathrm{A}$ of $\mathrm{C}=\mathrm{O}$ [144, 180-182]. Due to the low adsorbed amount of tetracycline, the infrared spectra of TC-ATMa and ATMa are relatively similar. The difference of these spectra is noticed on the increase in the intensity of the vibration band at $3394 \mathrm{~cm}^{-1}$ due to the adsorbed water. Moreover the intensities of the vibration bands of the $-\mathrm{OH}$ groups at 3527 and $3617 \mathrm{~cm}^{-1}$ have also significantly increased [183, 184]. On the GM spectrum, the bands at 1618 and $1551 \mathrm{~cm}^{-1}$ were observed and were assigned to the stretching of amide $\mathrm{I}$, and $\mathrm{C}=\mathrm{O}$, at ring A and ring C $[185,186]$, respectively. On the IR spectrum of TC-activated carbon, it was noticed the vibration bands at $1137,1441,1638$ and $3420 \mathrm{~cm}^{-1}$, were assigned to the stretching vibrations of C-O-C $\left(1137 \mathrm{~cm}^{-1}\right), \mathrm{C}-\mathrm{N}\left(1441 \mathrm{~cm}^{-1}\right), \mathrm{C}=\mathrm{O}\left(1638 \mathrm{~cm}^{-1}\right)$ and $\mathrm{O}-\mathrm{H}$ $\left(3420 \mathrm{~cm}^{-1}\right)$. The absence of the $-\mathrm{OH}$ band is noted on the TC-activated carbon_318K spectrum [187, 188]. However, a vibration band at $1551 \mathrm{~cm}^{-1}$ that appears on IR spectrum of $\mathrm{GM}$ was assigned to the $\mathrm{C}=\mathrm{C}$ stretching vibration at rings $[188,189]$. 


\section{Thermodynamic process}

The thermodynamic parameters of the adsorption process were determined from equation (9). $K_{d}$ is the distribution coefficient. The plot of $K_{d}$ as function of $1 / T$ was illustrated in Figure 6c. The thermodynamic parameters were gathered in Table 6.

Thermodynamic parameters of TC adsorption on GM, activated carbon and ATMa

Table 6

\begin{tabular}{|c|c|c|c|c|}
\hline Adsorbents & $\begin{array}{c}T \\
{[\mathbf{K}]}\end{array}$ & $\begin{array}{c}\Delta H^{\circ} \\
{\left[\mathbf{k J} \cdot \mathbf{m o l}^{-1}\right]}\end{array}$ & $\begin{array}{c}\Delta S^{\circ} \\
{\left[\mathrm{kJ} \cdot(\mathrm{K} \cdot \mathrm{mol})^{-1}\right]}\end{array}$ & $\begin{array}{c}\Delta G^{\circ} \\
{\left[\mathrm{kJ} \cdot \mathrm{mol}^{-1}\right]}\end{array}$ \\
\hline \multirow{3}{*}{ GM } & 298 & \multirow{3}{*}{48.78} & \multirow{3}{*}{0.15} & 4.08 \\
\hline & 308 & & & 2.58 \\
\hline & 318 & & & 1.08 \\
\hline \multirow{3}{*}{ Activated carbon } & 298 & \multirow{3}{*}{69.86} & \multirow{3}{*}{0.25} & -4.64 \\
\hline & 308 & & & -7.14 \\
\hline & 318 & & & -9.64 \\
\hline \multirow{3}{*}{ ATMa } & 298 & \multirow{3}{*}{5.67} & \multirow{3}{*}{0.01} & 2.69 \\
\hline & 308 & & & 2.59 \\
\hline & 318 & & & 2.49 \\
\hline
\end{tabular}

In Table 6 , it was noted that the $\Delta H^{\circ}$ values are positive and $\Delta G^{\circ}$ values decrease or even are negative (case of activated carbon), indicate that the adsorption process is endothermic and spontaneous [190, 191].

The positive value of entropy may be explained as an irregular increase of the randomness at the TC/adsorbent interface during the adsorption process [192, 193].

\section{Conclusion}

In the present study, a composite material (GM) was developed based on Algerian clay, activated carbon, cement and PVA polymer for containment of hazardous waste. The use of the composite and its mineral constituents for the tetracycline removal revealed that the adsorption kinetic of TC onto GM and clay is very fast and the equilibrium is reached within $30 \mathrm{~min}$. The kinetic is well fitted by pseudo-second-order and intraparticle diffusion models. The study also demonstrated that the removal of tetracycline onto GM is $\mathrm{pH}$ dependent. Indeed, $\mathrm{TC}$ retention was significant at acidic $\mathrm{pH}$. The adsorption capacity was better for activated carbon and GM composite compared to ATMa clay. It was noticed that the adsorption capacity increases with increasing temperature and the adsorption process is endothermic and spontaneous. Adsorption isotherms were described by Langmuir model for whole investigated adsorbents. The adsorption of TC was on the outer surface of the clay ATMa and GM as demonstrated by the XRD analysis. The characteristic groups of TC were identified by IR spectroscopy, which indicate that the tetracycline was adsorbed on the GM composite and its mineral constituents. Based on the obtained results, it was demonstrated that the development of new composites by low cost materials and methods were effective in removing potentially hazardous pollutants such as tetracycline.

\section{Acknowledgements}

This work was carried out at the IS2M institute, at the laboratory of Equipe des materiaux à porositécontrôllée de Mulhouse France, and funded by the Ministry of Higher Education and Research (Algeria). 


\section{References}

[1] Dai J, Becquer T, Rouiller JH, Reversat G, Bernhard-Reversat F, Lavelle P. Influence of heavy metals on C and $\mathrm{N}$ mineralisation and microbial biomass in $\mathrm{Zn}-, \mathrm{Pb}-, \mathrm{Cu}-$, and $\mathrm{Cd}$-contaminated soils. Appl Soil Ecol. 2004;25:99-109. DOI: 10.1016/j.apsoil.2003.09.003.

[2] Mirasgedis S, Hontou V, Georgopoulou E, Sarafidis Y, Gakis N, Lalas DP, et al. Environmental damage costs from airborne pollution of industrial activities in the greater Athens, Greece area and the resulting benefits from the introduction of BAT. Environ Impact Assess Rev. 2008;28:39-56. DOI: 10.1016/j.eiar.2007.03.006.

[3] Du YJ, Hayashi S. A study on sorption properties of $\mathrm{Cd}^{2+}$ on Ariake clay for evaluating its potential use as a landfill barrier material. Appl Clay Sci. 2006;32:14-24. DOI: 10.1016/j.clay.2006.01.003.

[4] Ololade OO, Mavimbela S, Oke SA, Makhadi R. Impact of leachate from northern landfill site in bloemfontein on water and soil quality: Implications for water and food security. Sustainability. 2019;11:4238. DOI: 10.3390/su11154238.

[5] Przydatek G, Kanownik W. Impact of small municipal solid waste landfill on groundwater quality. Environ Monit Assess. 2019;191:169. DOI: 10.1007/s10661-019-7279-5.

[6] Sun X-c, Xu Y, Liu Y-q, Nai C-x, Dong L, Liu J-c, et al. Evolution of geomembrane degradation and defects in a landfill: Impacts on long-term leachate leakage and groundwater quality. J Clean Prod. 2019;224:335-45. DOI: 10.1016/j.jclepro.2019.03.200.

[7] Mepaiyeda S, Madi K, Gwavava O, Baiyegunhi C. Geological and geophysical assessment of groundwater contamination at the Roundhill landfill site, Berlin, Eastern Cape, South Africa. Heliyon. 2020;6:e04249. DOI: 10.1016/j.heliyon.2020.e04249.

[8] Wu D, Sui Q, Yu X, Zhao W, Li Q, Fatta-Kassinos D, et al. Identification of indicator PPCPs in landfill leachates and livestock wastewaters using multiresidue analysis of 70 PPCPs: Analytical method development and application in Yangtze River Delta, China. Sci Total Environ. 2021;753:141653. DOI: 10.1016/j.scitotenv.2020.141653.

[9] Christensen TH, Kjeldsen P, Albrechtsen HJr, Heron G, Nielsen PH, Bjerg PL, et al. Attenuation of landfill leachate pollutants in aquifers. Crit Rev Environ Sci Technol. 1994;24:119-202. DOI: 10.1080/10643389409388463.

[10] Top S, Akkaya GK, Demir A, Yıldız Ş, Balahorli V, Bilgili MS. Investigation of leachate characteristics in field-scale landfill test cells. Int J Environ Res. 2019;13:829-42. DOI: 10.1007/s41742-019-00217-5.

[11] Nevondo V, Malehase T, Daso AP, Okonkwo OJ. Leachate seepage from landfill: a source of groundwater mercury contamination in South Africa. Water SA. 2019;45. DOI: 10.4314/wsa.v45i2.09.

[12] Gamoń F, Tomaszewski M, Ziembińska-Buczyńska A. Ecotoxicological study of landfill leachate treated in the ANAMMOX process. Water Qual Res J. 2019;54:230-41. DOI: 10.2166/wqrj.2019.042.

[13] Caroline Baettker E, Kozak C, Knapik HG, Aisse MM. Applicability of conventional and non-conventional parameters for municipal landfill leachate characterization. Chemosphere. 2020;251:126414. DOI: 10.1016/j.chemosphere.2020.126414.

[14] Nika MC, Ntaiou K, Elytis K, Thomaidi VS, Gatidou G, Kalantzi OI, et al. Wide-scope target analysis of emerging contaminants in landfill leachates and risk assessment using Risk Quotient methodology. J Hazard Mater. 2020;394:122493. DOI: 10.1016/j.jhazmat.2020.122493.

[15] Wang P, Wu D, You X, Su Y, Xie B. Antibiotic and metal resistance genes are closely linked with nitrogen-processing functions in municipal solid waste landfills. J Hazard Mater. 2021;403:123689. DOI: 10.1016/j.jhazmat.2020.123689.

[16] Kamiński W, Kuśmierek K, Świątkowski A, Tomczak E. Simultaneous adsorption of phenol derivatives from water onto spherical activated carbon. Ecol Chem Eng S. 2020;27:403-13. DOI: 10.2478/eces-2020-0026.

[17] King AG. Research advances: Eating clay; look to soil for new leads in arthritis treatment; The fate of tetracyclines. J Chem Educ. 2006;83:186-91. DOI: 10.1021/ed083p186.

[18] Wang YJ, Jia DA, Sun RJ, Zhu HW, Zhou DM. Adsorption and cosorption of tetracycline and copper(II) on montmorillonite as affected by solution pH. Environ Sci Technol. 2008;42:3254-9. DOI: 10.1021/es702641a.

[19] David JC, Buchet A, Sialelli JN, Delouvée S. The use of antibiotics in veterinary medicine: Representations of antibiotics and biosecurity by pig farmers. Prat Psychol. 2020. DOI: 10.1016/j.prps.2020.06.003.

[20] Zhu Y, Liu K, Zhang J, Liu X, Yang L, Wei R, et al. Antibiotic body burden of elderly Chinese population and health risk assessment: A human biomonitoring-based study. Environ Pollut. 2020;256:113311. DOI: 10.1016/j.envpol.2019.113311. 
[21] Yang Y, Bian L, Hang X, Yan C, Huang Y, Ye F, et al. In vitro activity of new tetracycline analogues omadacycline and eravacycline against clinical isolates of Helicobacter pylori collected in China. Diagn Microbiol Infect Dis. 2020;98:115129. DOI: 10.1016/j.diagmicrobio.2020.115129.

[22] Chan R, Wandee S, Wang M, Chiemchaisri W, Chiemchaisri C, Yoshimura C. Fate, transport and ecological risk of antibiotics from pig farms along the Bang Pakong River, Thailand. Agr Ecosyst Environ. 2020;304:107123. DOI: 10.1016/j.agee.2020.107123.

[23] Ji L, Chen W, Duan L, Zhu D. Mechanisms for strong adsorption of tetracycline to carbon nanotubes: A comparative study using activated carbon and graphite as adsorbents. Environ Sci Technol. 2009;43:2322-7. DOI: 10.1021/es803268b.

[24] Ji L, Chen W, Bi J, Zheng S, Xu Z, Zhu D, et al. Adsorption of tetracycline on single-walled and multi-walled carbon nanotubes as affected by aqueous solution chemistry. Environ Toxicol Chem. 2010;29:2713-9. DOI: 10.1002/etc.350.

[25] Li R, Yuan Q, Zhang Y, Ling J, Han T. Hydrophilic interaction chromatographic determination of oxytetracycline in the environmental water using silica column. J Liq Chromatogr R t. 2011;34:511-20. DOI: 10.1080/10826076.2011.556971.

[26] Sun H, Shi X, Mao J, Zhu D. Tetracycline sorption to coal and soil humic acids: An examination of humic structural heterogeneity. Environ Toxicol Chem. 2010;29:1934-42. DOI: 10.1002/etc.248.

[27] Mishra S, Tiwary D, Ohri A, Agnihotri AK. Impact of municipal solid waste landfill leachate on groundwater quality in Varanasi, India. Ground Sustain Dev. 2019;9:100230. DOI: 10.1016/j.gsd.2019.100230.

[28] Mittal A, Singh R, Chakma S, Goel G. Permeable reactive barrier technology for the remediation of groundwater contaminated with nitrate and phosphate resulted from pit-toilet leachate. J Water Process Eng. 2020;37:101471. DOI: 10.1016/j.jwpe.2020.101471.

[29] Rasheed T, Bilal M, Hassan AA, Nabeel F, Bharagava RN, Romanholo Ferreira LF, et al. Environmental threatening concern and efficient removal of pharmaceutically active compounds using metal-organic frameworks as adsorbents. Environ Res. 2020;185:109436. DOI: 10.1016/j.envres.2020.109436.

[30] Yadav B, Pandey AK, Kumar LR, Kaur R, Yellapu SK, Sellamuthu B, et al. Introduction to wastewater microbiology: special emphasis on hospital wastewater. In: Tyagi RD, Sellamuthu B, Tiwari B, Yan S, Drogui P, Zhang X, et al., editors. Current Developments in Biotechnology and Bioengineering: Elsevier; 2020;141. DOI: 10.1016/B978-0-12-819722-6.00001-8.

[31] Luczkiewicz A, Fudala-Ksiazek S, Jankowska K, Quant B, Olanczuk-Neyman, K. Diversity of fecal coliforms and their antimicrobial resistance patterns in wastewater treatment model plant. Water Sci Technol. 2010;61:1383-92. DOI: 10.2166/wst.2010.015.

[32] Hölzel CS, Harms KS, Küchenhoff H, Kunz A, Müller C, Meyer K, et al. Phenotypic and genotypic bacterial antimicrobial resistance in liquid pig manure is variously associated with contents of tetracyclines and sulfonamides. J Appl Microbiol. 2010;108:1642-56. DOI: 10.1111/j.1365-2672.2009.04570.x.

[33] Kumar KC. Gupta S, Chander Y, Singh AK. Antibiotic use in agriculture and its impact on the terrestrial environment. ADV AGRON: Academic Press; 2005;1-54. DOI: 10.1016/S0065-2113(05)87001-4.

[34] Hassoun-Kheir N, Stabholz Y, Kreft J-U, de la Cruz R, Romalde JL, Nesme J, et al. Comparison of antibiotic-resistant bacteria and antibiotic resistance genes abundance in hospital and community wastewater: A systematic review. Sci Total Environ. 2020;743:140804. DOI: 10.1016/j.scitotenv.2020.140804.

[35] Voigt AM, Zacharias N, Timm C, Wasser F, Sib E, Skutlarek D, et al. Association between antibiotic residues, antibiotic resistant bacteria and antibiotic resistance genes in anthropogenic wastewater An evaluation of clinical influences. Chemosphere. 2020;241:125032. DOI: 10.1016/j.chemosphere.2019.125032.

[36] Sun H, Bjerketorp J, Levenfors JJ, Schnürer A. Isolation of antibiotic-resistant bacteria in biogas digestate and their susceptibility to antibiotics. Environ Pollut. 2020;266:115265. DOI: 10.1016/j.envpol.2020.115265.

[37] López-de-la-Cruz J, Pérez-Aranda M, Alcudia A, Begines B, Caraballo T, Pajuelo E, et al. Dynamics and numerical simulations to predict empirical antibiotic treatment of multi-resistant Pseudomonas aeruginosa infection. Commun Nonlinear Sci Numer Simul. 2020;91:105418. DOI: 10.1016/j.cnsns.2020.105418.

[38] Kümmerer K. Antibiotics in the aquatic environment - A review - Part I. Chemosphere. 2009;75:417-34. DOI: 10.1016/j.chemosphere.2008.11.086.

[39] Kümmerer K. Antibiotics in the aquatic environment - A review - Part II. Chemosphere. 2009;75:435-41. DOI: 10.1016/j.chemosphere.2008.12.006.

[40] Yue Y, Shen C, Ge Y. Biochar accelerates the removal of tetracyclines and their intermediates by altering soil properties. J Hazard Mater. 2019;380:120821. DOI: 10.1016/j.jhazmat.2019.120821. 
[41] Santás-Miguel V, Arias-Estévez M, Díaz-Raviña M, Fernández-Sanjurjo MJ, Álvarez-Rodríguez E, Núñez-Delgado A, et al. Interactions between soil properties and tetracycline toxicity affecting to bacterial community growth in agricultural soil. Appl Soil Ecol. 2020;147:103437. DOI: 10.1016/j.apsoil.2019.103437.

[42] Xu L, Zhang H, Xiong P, Zhu Q, Liao C, Jiang G. Occurrence, fate, and risk assessment of typical tetracycline antibiotics in the aquatic environment: A review. Sci Total Environ. 2021;753:141975. DOI: 10.1016/j.scitotenv.2020.141975.

[43] Kulshrestha P, Giese RF, Aga DS. Investigating the molecular interactions of oxytetracycline in clay and organic matter: Insights on factors affecting its mobility in soil. Environ Sci Technol. 2004;38:4097-105. DOI: $10.1021 / \mathrm{es} 034856 \mathrm{q}$.

[44] Conde-Cid M, Fernández-Calviño D, Núñez-Delgado A, Fernández-Sanjurjo MJ, Arias-Estévez M, Álvarez-Rodríguez E. Estimation of adsorption/desorption Freundlich's affinity coefficients for oxytetracycline and chlortetracycline from soil properties: Experimental data and pedotransfer functions. Ecotoxicol Environ Saf. 2020;196:110584. DOI: 10.1016/j.ecoenv.2020.110584.

[45] Liu J, Yu F, Call DR, Mills DA, Zhang A, Zhao Z. On-farm soil resistome is modified after treating dairy calves with the antibiotic florfenicol. Sci Total Environ. 2020:141694. DOI: 10.1016/j.scitotenv.2020.141694.

[46] Xu H, Chen Z, Wu X, Zhao L, Wang N, Mao D, et al. Antibiotic contamination amplifies the impact of foreign antibiotic-resistant bacteria on soil bacterial community. Sci Total Environ. 2020:143693. DOI: 10.1016/j.scitotenv.2020.143693.

[47] $\mathrm{Xu} \mathrm{XR,} \mathrm{Li} \mathrm{XY.} \mathrm{Sorption} \mathrm{and} \mathrm{desorption} \mathrm{of} \mathrm{antibiotic} \mathrm{tetracycline} \mathrm{on} \mathrm{marine} \mathrm{sediments.} \mathrm{Chemosphere.}$ 2010;78:430-6. DOI: 10.1016/j.chemosphere.2009.10.045

[48] Peng Q, Song J, Li X, Yuan H, Liu M, Duan L, et al. Pharmaceutically active compounds (PhACs) in surface sediments of the Jiaozhou Bay, north China. Environ Pollut. 2020;266:115245. DOI: 10.1016/j.envpol.2020.115245.

[49] Lu L, Liu J, Li Z, Zou X, Guo J, Liu Z, et al. Antibiotic resistance gene abundances associated with heavy metals and antibiotics in the sediments of Changshou Lake in the three Gorges Reservoir area, China. Ecol Indic. 2020;113:106275. DOI: 10.1016/j.ecolind.2020.106275.

[50] Zhang Y, Chen H, Jing L, Teng Y. Ecotoxicological risk assessment and source apportionment of antibiotics in the waters and sediments of a peri-urban river. Sci Total Environ. 2020;731:139128. DOI: 10.1016/j.scitotenv.2020.139128.

[51] Lindsey ME, Meyer M, Thurman EM. Analysis of trace levels of sulfonamide and tetracycline antimicrobials in groundwater and surface water using solid-phase extraction and liquid chromatography/mass spectrometry. Anal Chem. 2001;73:4640-6. DOI: 10.1021/ac010514w.

[52] Nguyen CH, Fu C-C, Kao D-Y, Tran TTV, Juang R-S. Adsorption removal of tetracycline from water using poly(vinylidene fluoride)/polyaniline-montmorillonte mixed matrix membranes. J Taiwan Inst Chem Eng. 2020. DOI: 10.1016/j.jtice.2020.06.007.

[53] Li Z, Wang X, Xu N, Xiao Y, Ma L, Duan J. Cost-effective and visible-light-driven melamine-derived sponge for tetracyclines degradation and Salmonella inactivation in water. Chem Eng J. 2020;394:124913. DOI: $10.1016 /$ j.cej.2020.124913.

[54] Avisar D, Levin G, Gozlan I. The processes affecting oxytetracycline contamination of groundwater in a phreatic aquifer underlying industrial fish ponds in Israel. Environ Earth Sci. 2009;59:939-45. DOI: 10.1007/s12665-009-0088-3.

[55] Sapkota AR, Curriero FC, Gibson KE, Schwab KJ. Antibiotic-resistant enterococci and fecal indicators in surface water and groundwater impacted by a concentrated swine feeding operation. Environ Health Persp. 2007;115:1040-5. DOI: 10.1289/ehp.9770.

[56] Huang F, An Z, Moran MJ, Liu F. Recognition of typical antibiotic residues in environmental media related to groundwater in China (2009-2019). J Hazard Mater. 2020;399:122813. DOI: 10.1016/j.jhazmat.2020.122813.

[57] Szymczycha B, Borecka M, Białk-Bielińska A, Siedlewicz G, Pazdro K. Submarine groundwater discharge as a source of pharmaceutical and caffeine residues in coastal ecosystem: Bay of Puck, southern Baltic Sea case study. Sci Total Environ. 2020;713:136522. DOI: 10.1016/j.scitotenv.2020.136522.

[58] Miao XS, Bishay F, Chen M, Metcalfe CD. Occurrence of antimicrobials in the final effluents of wastewater treatment plants in Canada. Environ Sci Technol. 2004;38:3533-41. DOI: 10.1021/es030653q.

[59] Batt AL, Kim S, Aga DS. Comparison of the occurrence of antibiotics in four full-scale wastewater treatment plants with varying designs and operations. Chemosphere. 2007;68:428-35. DOI: 10.1016/j.Chemosphere.2007.01.008. 
[60] Cheng D, Ngo HH, Guo W, Chang SW, Nguyen DD, Zhang X, et al. Feasibility study on a new pomelo peel derived biochar for tetracycline antibiotics removal in swine wastewater. Sci Total Environ. 2020;720:137662. DOI: 10.1016/j.scitotenv.2020.137662.

[61] Ma S, Jing J, Liu P, Li Z, Jin W, Xie B, et al. High selectivity and effectiveness for removal of tetracycline and its related drug resistance in food wastewater through schwertmannite/graphene oxide catalyzed photo-Fenton-like oxidation. J Hazard Mater. 2020;392:122437. DOI: 10.1016/j.jhazmat.2020.122437.

[62] Xie W, Shi Y, Wang Y, Zheng Y, Liu H, Hu Q, et al. Electrospun iron/cobalt alloy nanoparticles on carbon nanofibers towards exhaustive electrocatalytic degradation of tetracycline in wastewater. Chem Eng J. 2021;405:126585. DOI: 10.1016/j.cej.2020.126585.

[63] Todorov B, Nedyalkova M, Simeonov V. Environmental effect of potential radiopharmaceuticals residuals. Ecol Chem Eng S. 2020;27:603-14. DOI: 10.2478/eces-2020-0038.

[64] Phoon BL, Ong CC, Mohamed Saheed MS, Show P-L, Chang J-S, Ling TC, et al. Conventional and emerging technologies for removal of antibiotics from wastewater. J Hazard Mater. 2020;400:122961. DOI: 10.1016/j.jhazmat.2020.122961.

[65] Pariente MI, Segura Y, Molina R, Martínez F. Chapter 2 - Wastewater treatment as a process and a resource. In: Olivares JA, Puyol D, Melero JA, Dufour J, editors. Wastewater Treatment Residues as Resources for Biorefinery Products and Biofuels. Elsevier; 2020;19-45. DOI: 10.1016/B978-0-12-816204-0.00002-3.

[66] Zaied BK, Rashid M, Nasrullah M, Zularisam AW, Pant D, Singh L. A comprehensive review on contaminants removal from pharmaceutical wastewater by electrocoagulation process. Sci Total Environ. 2020;726:138095. DOI: 10.1016/j.scitotenv.2020.138095.

[67] Gautam S, Agrawal H, Thakur M, Akbari A, Sharda H, Kaur R, et al. Metal oxides and metal organic frameworks for the photocatalytic degradation: A review. J Environ Chem Eng. 2020;8:103726. DOI: 10.1016/j.jece.2020.103726.

[68] Li Z, Chang PH, Jean JS, Jiang WT, Wang CJ. Interaction between tetracycline and smectite in aqueous solution. J Colloid Interface Sci. 2010;341:311-9. DOI: 10.1016/j.jcis.2009.09.054.

[69] Rajapaksha AU, Dilrukshi Premarathna KS, Gunarathne V, Ahmed A, Vithanage M. 9 - Sorptive removal of pharmaceutical and personal care products from water and wastewater. In: Prasad MNV, Vithanage M, Kapley A, editors. Pharmaceuticals and Personal Care Products: Waste Management and Treatment Technology. Butterworth-Heinemann; 2019;213-38. DOI: 10.1016/B978-0-12-816189-0.00009-3.

[70] da Rocha MC, Braz EMdA, Honório LMC, Trigueiro P, Fonseca MG, Silva-Filho EC, et al. Understanding the effect of UV light in systems containing clay minerals and tetracycline. Appl Clay Sci. 2019;183:105311. DOI: 10.1016/j.clay.2019.105311.

[71] ul Haque S, Nasar A, Inamuddin. 27 - Montmorillonite clay nanocomposites for drug delivery. In: Inamuddin, Asiri AM, Mohammad A, editors. Applications of Nanocomposite Materials in Drug Delivery: Woodhead Publishing; 2018. p. 633-48. DOI: 10.1016/B978-0-12-813741-3.00028-5.

[72] Scholtzová E. 6 - Computational modeling of nanoclays. In: Cavallaro G, Fakhrullin R, Pasbakhsh P, editors. Clay Nanoparticles. Elsevier; 2020. p. 139-66. DOI: 10.1016/B978-0-12-816783-0.00006-2.

[73] Wu M, Zhao S, Jing R, Shao Y, Liu X, Lv F, et al. Competitive adsorption of antibiotic tetracycline and ciprofloxacin on montmorillonite. Appl Clay Sci. 2019;180:105175. DOI: 10.1016/j.clay.2019.105175.

[74] Wen X, Zeng Z, Du C, Huang D, Zeng G, Xiao R, et al. Immobilized laccase on bentonite-derived mesoporous materials for removal of tetracycline. Chemosphere. 2019;222:865-71. DOI: 10.1016/j.chemosphere.2019.02.020.

[75] Chang P-H, Li Z, Jiang W-T, Jean J-S. Adsorption and intercalation of tetracycline by swelling clay minerals. Appl Clay Sci. 2009;46:27-36. DOI: 10.1016/j.clay.2009.07.002.

[76] Guo S, Yang W, You L, Li J, Chen J, Zhou K. Simultaneous reduction of Cr(VI) and degradation of tetracycline hydrochloride by a novel iron-modified rectorite composite through heterogeneous photo-Fenton processes. Chem Eng J. 2020;393:124758. DOI: 10.1016/j.cej.2020.124758.

[77] Li Z, Guo M, Sun X, Li L, Guo X, Huang L, et al. High concentration phosphate removal by calcite and its subsequent utilization for tetracycline removal. J Water Process Eng. 2020;37:101412. DOI: 10.1016/j.jwpe.2020.101412.

[78] Han H, Rafiq MK, Zhou T, Xu R, Mašek O, Li X. A critical review of clay-based composites with enhanced adsorption performance for metal and organic pollutants. J Hazard Mater. 2019;369:780-96. DOI: 10.1016/j.jhazmat.2019.02.003.

[79] Chang P-H, Li Z, Yu T-L, Munkhbayer S, Kuo T-H, Hung Y-C, et al. Sorptive removal of tetracycline from water by palygorskite. J Hazard Mater. 2009;165:148-55. DOI: 10.1016/j.jhazmat.2008.09.113.

[80] Wang W, Wang A. 2 - Palygorskite Nanomaterials: Structure, Properties, and Functional Applications. In: Wang A, Wang W, editors. Nanomaterials from Clay Minerals. Elsevier; 2019;21-133. DOI: 10.1016/B978-0-12-814533-3.00002-8. 


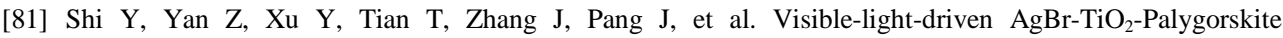
photocatalyst with excellent photocatalytic activity for tetracycline hydrochloride. J Clean Prod. 2020;277:124021. DOI: 10.1016/j.jclepro.2020.124021.

[82] Lian J, Ouyang Q, Tsang PE, Fang Z. Fenton-like catalytic degradation of tetracycline by magnetic palygorskite nanoparticles prepared from steel pickling waste liquor. Appl Clay Sci. 2019;182:105273. DOI: 10.1016/j.clay.2019.105273.

[83] Caroni ALPF, de Lima CRM, Pereira MR, Fonseca JLC. The kinetics of adsorption of tetracycline on chitosan particles. J Colloid Interface Sci. 2009;340:182-91. DOI: 10.1016/j.jcis.2009.08.016.

[84] Ranjbari S, Tanhaei B, Ayati A, Khadempir S, Sillanpää M. Efficient tetracycline adsorptive removal using tricaprylmethylammonium chloride conjugated chitosan hydrogel beads: Mechanism, kinetic, isotherms and thermodynamic study. Int J Biol Macromol. 2020;155:421-9. DOI: 10.1016/j.ijbiomac.2020.03.188.

[85] Topal M, Arslan Topal EI. Optimization of tetracycline removal with chitosan obtained from mussel shells using RSM. J Ind Eng Chem. 2020;84:315-21. DOI: 10.1016/j.jiec.2020.01.013.

[86] Ahamad T, Naushad M, Al-Shahrani T, Al-hokbany N, Alshehri SM. Preparation of chitosan based magnetic nanocomposite for tetracycline adsorption: Kinetic and thermodynamic studies. Int $\mathrm{J}$ Biol Macromol. 2020;147:258-67. DOI: 10.1016/j.ijbiomac.2020.01.025.

[87] Chen W-R, Huang C-H. Adsorption and transformation of tetracycline antibiotics with aluminum oxide. Chemosphere. 2010;79:779-85. DOI: 10.1016/j.chemosphere.2010.03.020.

[88] Hami HK, Abbas RF, Abdullwahid Jasim A, Abdul Abass DA, et al. Kinetics study of removal doxycycline drug from aqueous solution using aluminum oxide surface. Egypt J Chem. 2019;62:91-101. DOI: 10.21608/EJCHEM.2019.5499.1483.

[89] Mohammed AA, Kareem SL. Adsorption of tetracycline fom wastewater by using pistachio shell coated with $\mathrm{ZnO}$ nanoparticles: Equilibrium, kinetic and isotherm studies. Alex Eng J. 2019;58:917-28. DOI: 10.1016/j.aej.2019.08.006.

[90] Emzhina V, Kuzin E, Babusenko E, Krutchinina N. Photodegradation of tetracycline in presence of $\mathrm{H}_{2} \mathrm{O}_{2}$ and metal oxide based catalysts. J Water Process Eng. 2020:101696. DOI: 10.1016/j.jwpe.2020.101696.

[91] Xie D, Zhang H, Jiang M, Huang H, Zhang H, Liao Y, et al. Adsorptive removal of tetracycline from water using Fe(III)-functionalized carbonized humic acid. Chin J Chem Eng. 2020. DOI: 10.1016/j.cjche.2020.06.039.

[92] Yan C, Fan L, Chen Y, Xiong Y. Effective adsorption of oxytetracycline from aqueous solution by lanthanum modified magnetic humic acid. Colloids Surf A: Physicochem Eng Aspects. 2020;602:125135. DOI: $10.1016 /$ j.colsurfa.2020.125135.

[93] Choi K-J, Kim S-G, Kim S-H. Removal of antibiotics by coagulation and granular activated carbon filtration. J Hazard Mater. 2008;151:38-43. DOI: 10.1016/j.jhazmat.2007.05.059.

[94] Wang J, Lei S, Liang L. Preparation of porous activated carbon from semi-coke by high temperature activation with $\mathrm{KOH}$ for the high-efficiency adsorption of aqueous tetracycline. Appl Surf Sci. 2020;530:147187. DOI: 10.1016/j.apsusc.2020.147187.

[95] Yazidi A, Atrous M, Edi Soetaredjo F, Sellaoui L, Ismadji S, Erto A, et al. Adsorption of amoxicillin and tetracycline on activated carbon prepared from durian shell in single and binary systems: Experimental study and modeling analysis. Chem Eng J. 2020;379:122320. DOI: 10.1016/j.cej.2019.122320.

[96] Tan G, Mao Y, Wang H, Xu N. A comparative study of arsenic(V), tetracycline and nitrate ions adsorption onto magnetic biochars and activated carbon. Chem Eng Res Design. 2020;159:582-91. DOI: 10.1016/j.cherd.2020.05.011.

[97] Ray SS, Gusain R, Kumar N. Chapter 9. One-dimensional carbon nanomaterials-based adsorbents. In: Ray SS, Gusain R, Kumar N, editors. Carbon Nanomaterial-Based Adsorbents for Water Purification. Elsevier; 2020;195-224. DOI: 10.1016/B978-0-12-821959-1.00009-X.

[98] Chen C, Feng X, Yao S. Ionic liquid-multi walled carbon nanotubes composite tablet for continuous adsorption of tetracyclines and heavy metals. J Clean Prod. 2020:124937. DOI: 10.1016/j.jclepro.2020.124937.

[99] Zhao W, Tian Y, Chu X, Cui L, Zhang H, Li M, et al. Preparation and characteristics of a magnetic carbon nanotube adsorbent: Its efficient adsorption and recoverable performances. Sep Purif Technol. 2021;257:117917. DOI: 10.1016/j.seppur.2020.117917.

[100] Ait Hamoudi S, Hamdi B, Brendlé J, Kessaissia Z. Adsorption of lead by geomaterial matrix: Adsorption equilibrium and kinetics. Sep Sci Technol. 2014;49:1416-26. DOI: 10.1080/01496395.2013.879313.

[101] Cuevas J, Ruiz A, Fernández R, González-Santamaría D, Angulo M, Ortega A, et al. Authigenic clay minerals from interface reactions of concrete-clay engineered barriers: A new perspective on $\mathrm{Mg}$-clays formation in alkaline environments. Minerals. 2018;8:362. DOI: 10.3390/min8090362. 
[102] Wang J, Ma B, Tan H, Du C, Chu Z, Luo Z, et al. Hydration and mechanical properties of cement-marble powder system incorporating triisopropanolamine. Constr Build Mater. 2021;266:121068. DOI: 10.1016/j.conbuildmat.2020.121068.

[103] Muñoz P, Letelier V, Bustamante MA, Marcos-Ortega J, Sepúlveda JG. Assessment of mechanical, thermal, mineral and physical properties of fired clay brick made by mixing kaolinitic red clay and paper pulp residues. Appl Clay Sci. 2020;198:105847. DOI: 10.1016/j.clay.2020.105847.

[104] Brunauer S, Emmett PH, Teller E. Adsorption of gases in multimolecular layers. J Am Chem Soc. 1938;60:309-19. DOI: 10.1021/ja01269a023.

[105] Gibson N, Kuchenbecker P, Rasmussen K, Hodoroaba V-D, Rauscher H. Chapter 4.1 - Volume-specific surface area by gas adsorption analysis with the BET method. In: Hodoroaba V-D, Unger WES, Shard AG, editors. Characterization of Nanoparticles. Elsevier; 2020;265-94. DOI: 10.1016/B978-0-12-8141823.00017-1.

[106] Tripathi M, Bhatnagar A, Mubarak NM, Sahu JN, Ganesan P. RSM optimization of microwave pyrolysis parameters to produce OPS char with high yield and large BET surface area. Fuel. 2020;277:118184. DOI: 10.1016/j.fuel.2020.118184.

[107] Guibal E, Milot C, Tobin JM. Metal-anion sorption by chitosan beads: Equilibrium and kinetic studies. Ind Eng Chem Res. 1998;37:1454-63. DOI: 10.1021/ie970395.4.

[108] Ramirez A, Ocampo R, Giraldo S, Padilla E, Flórez E, Acelas N. Removal of Cr(VI) from an aqueous solution using an activated carbon obtained from teakwood sawdust: Kinetics, equilibrium, and density functional theory calculations. J Environ Chem Eng. 2020;8:103702. DOI: 10.1016/j.jece.2020.103702.

[109] Freundlich H. Über die adsorption in Losungen. Z Phys Chem. 1906;57:385-470. DOI: 10.1515/zpch-1907-5723.

[110] Walsh K, Mayer S, Rehmann D, Hofmann T, Glas K. Equilibrium data and its analysis with the Freundlich model in the adsorption of arsenic(V) on granular ferric hydroxide. Sep Purif Technol. 2020;243:116704. DOI: 10.1016/j.seppur.2020.116704.

[111] Langmuir I. The adsorption of gases on plane surfaces of glass, Micaand platinum. J Am Chem Soc. 1918;40:1361-403. DOI: 10.1021/ja02242a004.

[112] Guo X, Wang J. Comparison of linearization methods for modeling the Langmuir adsorption isotherm. J Mol Liq. 2019;296:111850. DOI: 10.1016/j.jiec.2020.01.013.

[113] Oubagaranadin JUK, Murthy ZVP. Isotherm modeling and batch adsorber design for the adsorption of $\mathrm{Cu}$ (II) on a clay containing montmorillonite. Appl Clay Sci. 2010;50:409-13. DOI: 10.1016/j.clay.2010.09.008.

[114] Aguayo-Villarreal IA, Cortes-Arriagada D, Rojas-Mayorga CK, Pineda-Urbina K, Muñiz-Valencia R, González J. Importance of the interaction adsorbent-adsorbate in the dyes adsorption process and DFT modeling. J Mol Struct. 2020;1203:127398. DOI: 10.1016/j.molstruc.2019.127398.

[115] Namasivayam C, Senthilkumar, S. Recycling of industrial solid waste for the removal of mercury(II) by adsorption process. Chemosphere. 1997;34:357-75. DOI: 10.1016/S0045-6535(96)00383-9.

[116] Akinbulumo OA, Odejobi OJ, Odekanle EL. Thermodynamics and adsorption study of the corrosion inhibition of mild steel by Euphorbia heterophylla L. extract in $1.5 \mathrm{M} \mathrm{HCl}$. Results Materials. 2020;5:100074. DOI: 10.1016/j.rinma.2020.100074.

[117] Amari A, Chlendi M, Gannouni A, Bellagi A. Optimised activation of bentonite for toluene adsorption. Appl Clay Sci. 2010;47:457-61. DOI: 10.1016/j.clay.2009.11.035.

[118] Sing KSW, Everet D, Haul R, Moscou L, Pierotti R, Rouquerol J, et al. Reporting physisorption data for gas/solid systems with special reference to the determination of surface area and porosity. Pure Appl Chem. 1985;57:603-19. DOI: 10.1351/pac198557040603.

[119] Shahrashoub M, Bakhtiari S. The efficiency of activated carbon/magnetite nanoparticles composites in copper removal: Industrial waste recovery, green synthesis, characterization, and adsorption-desorption studies. Micropor Mesopor Mater. 2021;311:110692. DOI: 10.1016/j.micromeso.2020.110692.

[120] Xiao F, Yan B-Q, Zou X-Y, Cao X-Q, Dong L, Lyu X-J, et al. Study on ionic liquid modified montmorillonite and molecular dynamics simulation. Colloids Surf A. Physicochem Eng Asp. 2020;587:124311. DOI: 10.1016/j.colsurfa.2019.124311.

[121] Tsai WT, Su TY, Hsu HC, Lin KY, Lin CM, Tai TH. Preparation of mesoporous solids by acid treatment of a porphyritic andesite (wheat-rice-stone). Micropor Mesopor Mater. 2007;102:196-203. DOI: 10.1016/j.micromeso.2006.12.036.

[122] Chu Y, Zhu S, Xia M, Wang F, Lei W. Methionine-montmorillonite composite - A novel material for efficient adsorption of lead ions. Adv Powder Technol. 2020;31:708-17. DOI: 10.1016/j.apt.2019.11.026.

[123] Barsotti E, Tan SP, Piri M, Chen J-H. Capillary-condensation hysteresis in naturally-occurring nanoporous media. Fuel. 2020;263:116441. DOI: 10.1016/j.fuel.2019.116441. 
[124] Lu X, Tang B, Zhang Q, Liu L, Fan R, Zhang Z. The presence of Cu facilitates adsorption of tetracycline (TC) onto water hyacinth roots. Int J Environ Res Public Health. 2018;15:1982. DOI: 10.3390/ijerph15091982.

[125] Shen H, Ie I-R, Yuan C-S, Hung C-H, Liu C-W. Adsorption phenomenon and kinetic mechanisms of $\mathrm{HgO}$ and $\mathrm{HgCl}_{2}$ by innovative composite sulfurized activated carbons. Fuel. 2019;256:115894. DOI: 10.1016/j.fuel.2019.115894.

[126] Zhang X, Lin X, He Y, Luo X. Phenolic hydroxyl derived copper alginate microspheres as superior adsorbent for effective adsorption of tetracycline. Int $\mathrm{J}$ Biol Macromol. 2019;136:445-59. DOI: 10.1016/j.ijbiomac.2019.05.165.

[127] Acemioğlu B. Batch kinetic study of sorption of methylene blue by perlite. Chem Eng J. 2005;106:73-81. DOI: 10.1016/j.cej.2004.10.005.

[128] Kannan N, Meenakshisundaram M. Adsorption of Congo Red on various activated carbons. A comparative study. Water Air Soil Pollut. 2002;138:289-305. DOI: 10.1023/A:1015551413378.

[129] Kuang Y, Zhang X, Zhou S. Adsorption of Methylene Blue in water onto activated carbon by surfactant modification. Water. 2020;12:587. DOI: 10.3390/w12020587.

[130] Pholosi A, Naidoo EB, Ofomaja AE. Intraparticle diffusion of $\mathrm{Cr}(\mathrm{VI})$ through biomass and magnetite coated biomass: A comparative kinetic and diffusion study. S Afr J Chem Eng. 2020;32:39-55. DOI: 10.1016/j.sajce.2020.01.005.

[131] Pauletto PS, Dotto GL, Salau NPG. Diffusion mechanisms and effect of adsorbent geometry on heavy metal adsorption. Chem Eng Res Des. 2020;157:182-94. DOI: 10.1016/j.cherd.2020.02.031.

[132] Bulut E, Özacar M, Şengil İA. Adsorption of malachite green onto bentonite: Equilibrium and kinetic studies and process design. Micropor Mesopor Mater. 2008;115:234-46. DOI: 10.1016/j.micromeso.2008.01.039.

[133] Maliyekkal SM, Shukla S, Philip L, Nambi IM. Enhanced fluoride removal from drinking water by magnesia-amended activated alumina granules. Chem Eng J. 2008;140:183-92. DOI: 10.1016/j.cej.2007.09.049.

[134] Souza PR, Dotto GL, Salau NPG. Experimental and mathematical modeling of hindered diffusion effect of cationic dye in the adsorption onto bentonite. J Environ Chem Eng. 2019;7:102891. DOI: 10.1016/j.jece.2019.102891.

[135] Lin Z, Hu Y, Yuan Y, Hu B, Wang B. Comparative analysis of kinetics and mechanisms for Pb(II) sorption onto three kinds of microplastics. Ecotoxicol Environ Saf. 2021;208:111451. DOI: 10.1016/j.ecoenv.2020.111451.

[136] Panday KK, Prasad G, Singh VN. Use of wollastonite for the treatment of $\mathrm{Cu}$ (II) rich effluents. Water Air Soil Pollut. 1986;27:287-96. DOI: 10.1007/BF00649410.

[137] Moghimi F, Jafari AH, Yoozbashizadeh H, Askari M. Adsorption behavior of Sb(III) in single and binary $\mathrm{Sb}$ (III)-Fe(II) systems on cationic ion exchange resin: Adsorption equilibrium, kinetic and thermodynamic aspects. Trans Nonferrous Met Soc. 2020;30:236-48. DOI: 10.1016/S1003-6326(19)65195-2.

[138] Mate CJ, Mishra S. Synthesis of borax cross-linked Jhingan gum hydrogel for remediation of Remazol Brilliant Blue R (RBBR) dye from water: Adsorption isotherm, kinetic, thermodynamic and biodegradation studies. Int J Biol Macromol. 2020;151:677-90. DOI: 10.1016/j.ijbiomac.2020.02.192.

[139] Wessels JM, Ford WE, Szymczak W, Schneider S. The complexation of tetracycline and anhydrotetracycline with $\mathrm{Mg}^{2+}$ and $\mathrm{Ca}^{2+}$ : A spectroscopic study. J Phys Chem B. 1998;102:9323-31. DOI: $10.1021 /$ jp9824050.

[140] Soori MM, Ghahramani E, Kazemian H, Al-Musawi TJ, Zarrabi M. Intercalation of tetracycline in nano sheet layered double hydroxide: An insight into UV/VIS spectra analysis. J Taiwan Inst Chem Engineers. 2016;63:271-85. DOI: 10.1016/j.jtice.2016.03.015.

[141] Song Y, Sackey EA, Wang H, Wang H. Adsorption of oxytetracycline on kaolinite. PLoS ONE. 2019;14:e0225335-e. DOI: 10.1371/journal.pone.0225335.

[142] Yuan L, Yan M, Huang Z, He K, Zeng G, Chen A, et al. Influences of pH and metal ions on the interactions of oxytetracycline onto nano-hydroxyapatite and their co-adsorption behavior in aqueous solution. J Colloid Interface Sci. 2019;541:101-13. DOI: 10.1016/j.jcis.2019.01.078.

[143] Gu X, Evans LJ, Barabash SJ. Modeling the adsorption of $\mathrm{Cd}$ (II), $\mathrm{Cu}$ (II), Ni(II), $\mathrm{Pb}$ (II) and $\mathrm{Zn}$ (II) onto montmorillonite. Geochim Cosmochim Acta. 2010;74:5718-28. DOI: 10.1016/j.gca.2010.07.016.

[144] Chahardahmasoumi S, Sarvi MN, Jalali SAH. Modified montmorillonite nanosheets as a nanocarrier with smart pH-responsive control on the antimicrobial activity of tetracycline upon release. Appl Clay Sci. 2019;178:105135. DOI: 10.1016/j.clay.2019.105135.

[145] Westerhoff P, Yoon Y, Snyder S, Wert E. Fate of endocrine-disruptor, pharmaceutical, and personal care product chemicals during simulated drinking water treatment processes. Environ Sci Technol. 2005;39:6649-63. DOI: 10.1021/es0484799. 
[146] Wang B, Xu X, Tang H, Mao Y, Chen H, Ji F. Highly efficient adsorption of three antibiotics from aqueous solutions using glucose-based mesoporous carbon. Appl Surf Sci. 2020;528:147048. DOI: 10.1016/j.apsusc.2020.147048.

[147] Huízar-Félix AM, Aguilar-Flores C, Martínez-de-la Cruz A, Barandiarán JM, Sepúlveda-Guzmán S, Cruz-Silva R. Removal of tetracycline pollutants by adsorption and magnetic separation using reduced graphene oxide decorated with $\alpha-\mathrm{Fe}_{2} \mathrm{O}_{3}$ nanoparticles. Nanomaterials. 2019;9:313. DOI: 10.3390/nano9030313.

[148] Radovic LR, Moreno-Castilla, C., Rivera-Utrilla, J. Carbon materials as adsorbents in aqueous solutions. In: Thrower PA, editor. Chemistry and Physics of Carbon. Marcel Dekker; 2001;27:227-405. ISBN: 9780429152658.

[149] Shamsudin MS, Azha SF, Sellaoui L, Badawi M, Al-Ghamdi YO, Bonilla-Petriciolet A, et al. Fabrication and characterization of a thin coated adsorbent for antibiotic and analgesic adsorption: Experimental investigation and statistical physical modelling. Chem Eng J. 2020;401:126007. DOI: 10.1016/j.cej.2020.126007.

[150] Coughlin RW, Ezra FS. Role of surface acidity in the adsorption of organic pollutants on the surface of carbon. Environ Sci Technol. 1968;2:291-7. DOI: 10.1021/es60016a002.

[151] Yi L, Zuo L, Wei C, Fu H, Qu X, Zheng S, et al. Enhanced adsorption of bisphenol A, tylosin, and tetracycline from aqueous solution to nitrogen-doped multiwall carbon nanotubes via cation- $\pi$ and $\pi-\pi$ electron-donor-acceptor (EDA) interactions. Sci Total Environ. 2020;719:137389. DOI: 10.1016/j.scitotenv.2020.137389.

[152] Cunha MR, Lima EC, Lima DR, da Silva RS, Thue PS, Seliem MK, et al. Removal of captopril pharmaceutical from synthetic pharmaceutical-industry wastewaters: Use of activated carbon derived from Butia catarinensis. J Environ Chem Eng. 2020;8:104506. DOI: 10.1016/j.jece.2020.104506.

[153] Yu X, Sun W, Ni J. LSER model for organic compounds adsorption by single-walled carbon nanotubes: Comparison with multi-walled carbon nanotubes and activated carbon. Environ Pollut. 2015;206:652-60. DOI: 10.1016/j.envpol.2015.08.031.

[154] Gao B, Li P, Yang R, Li A, Yang H. Investigation of multiple adsorption mechanisms for efficient removal of ofloxacin from water using lignin-based adsorbents. Sci Rep. 2019;9:637. DOI: 10.1038/s41598-018-37206-1.

[155] Choi K-J, Kim S-G, Kim C-W, Kim S-H. Determination of antibiotic compounds in water by on-line SPE-LC/MSD. Chemosphere. 2007;66:977-84. DOI: 10.1016/j.chemosphere.2006.07.037.

[156] Hernández-Monje D, Giraldo L, Moreno-Piraján JC. Interaction between hydrocarbons C6 and modified activated carbons: Correlation between adsorption isotherms and immersion enthalpies. ACS Omega. 2019;4:19595-604. DOI: 10.1021/acsomega.9b02062.

[157] Kerkez-Kuyumcu Ö, Bayazit ŞS, Salam MA. Antibiotic amoxicillin removal from aqueous solution using magnetically modified graphene nanoplatelets. Ind Eng Chem Res. 2016;36:198-205. DOI: 10.1016/j.jiec.2016.01.040

[158] Faysal Hossain MD, Akther N, Zhou Y. Recent advancements in graphene adsorbents for wastewater treatment: Current status and challenges. Chin Chem Lett. 2020;31:2525-38. DOI: 10.1016/j.cclet.2020.05.011.

[159] Tessmer CH, Vidic RD, Uranowski LJ. Impact of oxygen-containing surface functional groups on activated carbon adsorption of phenols. Environ Sci Technol. 1997;31:1872-8. DOI: 10.1021/es960474r.

[160] Eder S, Müller K, Azzari P, Arcifa A, Peydayesh M, Nyström L. Mass transfer mechanism and equilibrium modelling of hydroxytyrosol adsorption on olive pit-derived activated carbon. Chem Eng J. 2021;404:126519. DOI: 10.1016/j.cej.2020.126519.

[161] Lu Q, George A. Sorial. Adsorption of phenolics on activated carbon-impact of pore size and molecular oxygen. Chemosphere. 2004;55:671-9. DOI: 10.1016/j.Chemosphere.2003.11.044.

[162] Ang TN, Young BR, Taylor M, Burrell R, Aroua MK, Chen W-H, et al. Enrichment of surface oxygen functionalities on activated carbon for adsorptive removal of sevoflurane. Chemosphere. 2020;260:127496. DOI: 10.1016/j.chemosphere.2020.127496.

[163] Uranowski LJ, Tessmer CH, Vidic RD. The effect of surface metal oxides on activated carbon adsorption of phenolics. Water Res. 1998;32:1841-51. DOI: 10.1016/S0043-1354(97)00479-X.

[164] Gu C, Karthikeyan KG. Interaction of tetracycline with aluminum and iron hydrous oxides. Environ Sci Technol. 2005;39:2660-7. DOI: 10.1021/es048603o.

[165] Yang J, Dou Y, Yang H, Wang D. A novel porous carbon derived from $\mathrm{CO}_{2}$ for high-efficient tetracycline adsorption: Behavior and mechanism. App Surf Sci. 2021;538:148110. DOI: 10.1016/j.apsusc.2020.148110. 
[166] Hu Y, Chen C, Yang L, Cui J, Hao Q, Sun D. Handy purifier based on bacterial cellulose and Ca-montmorillonite composites for efficient removal of dyes and antibiotics. Carbohydr Polym. 2019;222:115017. DOI: 10.1016/j.carbpol.2019.115017.

[167] Liu N, Wang Mx, Liu Mm, Liu F, Weng L, Koopal LK, et al. Sorption of tetracycline on organo-montmorillonites. J Hazard Mater. 2012;225-226:28-35. DOI: 10.1016/j.jhazmat.2012.04.060.

[168] Salaa F, Bendenia S, Lecomte-Nana GL, Khelifa A. Enhanced removal of diclofenac by an organohalloysite intercalated via a novel route: Performance and mechanism. Chem Eng J. 2020;396:125226. DOI: 10.1016/j.cej.2020.125226.

[169] Mosaleheh N, Sarvi MN. Minimizing the residual antimicrobial activity of tetracycline after adsorption into the montmorillonite: Effect of organic modification. Environ Res. 2020;182:109056. DOI: 10.1016/j.envres.2019.109056.

[170] Ahmed MJ. Adsorption of quinolone, tetracycline, and penicillin antibiotics from aqueous solution using activated carbons: Environ Toxicol Pharmacol. 2017;50:1-10. DOI: 10.1016/j.etap.2017.01.004.

[171] Khawaja H, Zahir E, Asghar MA, Asghar MA. Graphene oxide decorated with cellulose and copper nanoparticle as an efficient adsorbent for the removal of malachite green. Int $\mathrm{J}$ Biol Macromol. 2021;167:23-34. DOI: 10.1016/j.ijbiomac.2020.11.137.

[172] Hamdaoui O, Naffrechoux E. Modeling of adsorption isotherms of phenol and chlorophenols onto granular activated carbon: Part I. Two-parameter models and equations allowing determination of thermodynamic parameters. J Hazard Mater. 2007;147:381-94. DOI: 10.1016/j.jhazmat.2007.01.021.

[173] Arellano-Cárdenas S, López-Cortez S, Cornejo-Mazón M, Mares-Gutiérrez JC. Study of malachite green adsorption by organically modified clay using a batch method. Appl Surf Sci. 2013;280:74-8. DOI: 10.1016/j.apsusc.2013.04.097.

[174] Tran HV, Hoang LT, Huynh CD. An investigation on kinetic and thermodynamic parameters of methylene blue adsorption onto graphene-based nanocomposite. Chem Phys. 2020;535:110793. DOI: 10.1016/j.chemphys.2020.110793.

[175] Zembrzuska J, Ginter-Kramarczyk D, Zając A, Kruszelnicka I, Michałkiewicz M, Dymaczewski Z, et al. The influence of temperature changes in activated sludge processes on ibuprofen removal efficiency. Ecol Chem Eng S. 2019;26:357-66. DOI: 10.1515/eces-2019-0025.

[176] Hamilton AR, Roberts M, Hutcheon GA, Gaskell EE. Formulation and antibacterial properties of clay mineral-tetracycline and doxycycline composites. Appl Clay Sci. 2019;179:105148. DOI: 10.1016/j.clay.2019.105148.

[177] Porubcan LS, Serna CJ, White JL, Hem SL. Mechanism of adsorption of clindamycin and tetracycline by montmorillonite. J Pharm Sci. 1978;67:1081-7. DOI: 10.1002/jps.2600670815.

[178] Maged A, Iqbal J, Kharbish S, Ismael IS, Bhatnagar A. Tuning tetracycline removal from aqueous solution onto activated 2:1 layered clay mineral: Characterization, sorption and mechanistic studies. J Hazard Mater. 2020;384:121320. DOI: 10.1016/j.jhazmat.2019.121320.

[179] Wang H, Zhang J, Wang P, Yin L, Tian Y, Li J. Bifunctional copper modified graphitic carbon nitride catalysts for efficient tetracycline removal: Synergy of adsorption and photocatalytic degradation. Chin Chem Lett. 2020;31:2789-94. DOI: 10.1016/j.cclet.2020.07.043.

[180] Chang P-H, Li Z, Jean J-S, Jiang W-T, Wang C-J, Lin K-H. Adsorption of tetracycline on 2:1 layered non-swelling clay mineral illite. Appl Clay Sci. 2012;67-68:158-63. DOI: 10.1016/j.clay.2011.11.004.

[181] Zhao Y, Gu X, Li S, Han R, Wang G. Insights into tetracycline adsorption onto kaolinite and montmorillonite: experiments and modeling. Environ Sci Pollut. 2015;22:17031-40. DOI: 10.1007/s11356-015-4839-2.

[182] Wang W, Lu T, Chen Y, Tian G, Sharma VK, Zhu Y, et al. Mesoporous silicate/carbon composites derived from dye-loaded palygorskite clay waste for efficient removal of organic contaminants. Sci Total Environ. 2019;696:133955. DOI: 10.1016/j.scitotenv.2019.133955.

[183] Parolo ME, Savini MC, Vallés JM, Baschini MT, Avena MJ. Tetracycline adsorption on montmorillonite: pH and ionic strength effects. Appl Clay Sci. 2008;40:179-86. DOI: 10.1016/j.clay.2007.08.003.

[184] Abdel-Karim A, El-Naggar ME, Radwan EK, Mohamed IM, Azaam M, Kenawy E-R. High-performance mixed-matrix membranes enabled by organically/inorganic modified montmorillonite for the treatment of hazardous textile wastewater. Chem Eng J. 2021;405:126964. DOI: 10.1016/j.cej.2020.126964.

[185] Zhao Y, Tong F, Gu X, Gu C, Wang X, Zhang Y. Insights into tetracycline adsorption onto goethite: Experiments and modeling. Sci Total Environ. 2014;470-471:19. DOI: 10.1016/j.scitotenv.2013.09.059.

[186] Gopal G, Sankar H, Natarajan C, Mukherjee A. Tetracycline removal using green synthesized bimetallic nZVI-Cu and bentonite supported green nZVI-Cu nanocomposite: A comparative study. J Environ Manage. 2020;254:109812. DOI: 10.1016/j.jenvman.2019.109812. 
[187] Huang L, Sun Y, Wang W, Yue Q, Yang T. Comparative study on characterization of activated carbons prepared by microwave and conventional heating methods and application in removal of oxytetracycline (OTC). Chem Eng J. 2011;171:1446-53. DOI: 10.1016/j.cej.2011.05.041.

[188] Chang J, Shen Z, Hu X, Schulman E, Cui C, Guo Q, et al. Adsorption of tetracycline by shrimp shell waste from aqueous solutions: adsorption isotherm, kinetics modeling, and mechanism. ACS Omega. 2020;5:3467-77. DOI: 10.1021/acsomega.9b03781.

[189] Kim S, Eichhorn P, Jensen JN, Weber AS, Aga DS. Removal of antibiotics in wastewater: effect of hydraulic and solid retention times on the fate of tetracycline in the activated sludge process. Environ Sci Technol. 2005;39:5816-23. DOI: 10.1021/es050006u.

[190] Zhang L, Song X, Liu X, Yang L, Pan F, Lv J. Studies on the removal of tetracycline by multi-walled carbon nanotubes. Chem Eng J. 2011;178:26-33. DOI: 10.1016/j.cej.2011.09.127.

[191] Ofudje EA, Adeogun IA, Idowu MA, Kareem SO, Ndukwe NA. Simultaneous removals of cadmium(II) ions and reactive yellow 4 dye from aqueous solution by bone meal-derived apatite: kinetics, equilibrium and thermodynamic evaluations. Anal Sci Technol. 2020;11:7. DOI: 10.1186/s40543-020-0206-0.

[192] Shao L, Ren Z, Zhang G, Chen L. Facile synthesis, characterization of a $\mathrm{MnFe}_{2} \mathrm{O}_{4} /$ activated carbon magnetic composite and its effectiveness in tetracycline removal. Mater Chem Phys. 2012;135:16-24. DOI: 10.1016/j.matchemphys.2012.03.035.

[193] Aswin Kumar I, Viswanathan N. Fabrication of zirconium(IV) cross-linked alginate/kaolin hybrid beads for nitrate and phosphate retention. Arab J Chem. 2020;13:4111-25. DOI: 10.1016/j.arabjc.2019.06.006. 